\title{
WestVirginiaUniversity
}

THE RESEARCH REPOSITORY @ WVU

West Virginia Agricultural and Forestry Experiment

Davis College of Agriculture, Natural Resources

Station Bulletins

And Design

$1-1-1961$

\section{Consumer purchases and preferences in landscaping}

Roger W. Pease

Follow this and additional works at: https://researchrepository.wvu.edu/ wv_agricultural_and_forestry_experiment_station_bulletins

\section{Digital Commons Citation}

Pease, Roger W., "Consumer purchases and preferences in landscaping" (1961). West Virginia Agricultural and Forestry Experiment Station Bulletins. 462.

https://researchrepository.wvu.edu/wv_agricultural_and_forestry_experiment_station_bulletins/437 @ WVU. It has been accepted for inclusion in West Virginia Agricultural and Forestry Experiment Station Bulletins by an authorized administrator of The Research Repository @ WVU. For more information, please contact ian.harmon@mail.wvu.edu. 
West Virginia University Libraries 
Digitized by the Internet Archive in 2010 with funding from

Lyrasis Members and Sloan Foundation 
Bulletin 462

June 1961

\section{Consumer Purchases}

\section{and Preferences}

In Landscaping

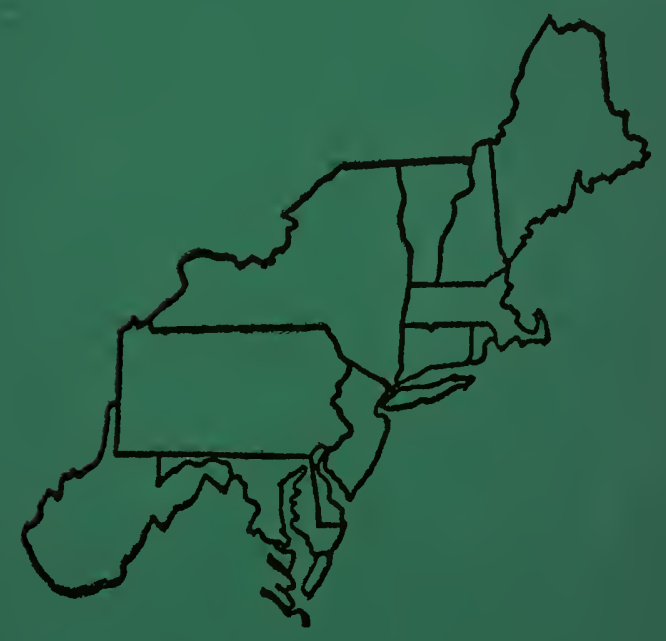

\section{WEST VIRGINIA UNIVERSITY} AGRICULTURAL EXPERIMENT STATION 


\section{Consumer Purchases and}

\section{Preferences \\ In \\ Landscaping}

By

ROGER W. PEASE

WEST VIRGINIA UNIVERSITY

AGRICULTURAL EXPERIMENT STATION 


\title{
PREPARATION OF MANUSCRIPT
}

The manuscript, Consumer Purchases and Preferences in Landscaping, was prepared by Roger W. Pease, Assistant Agricultural Economist, West Virginia University Agricultural Experiment Station.

\author{
WEST ViRgINIA UNIVERSITY \\ Agricultural EXPERIMENT Station \\ College of Agriculture, Forestry, and Home Economics \\ A. H. Vanlandingham, Director \\ MORGANTOWN
}




\section{CONSUMER PURCHASES AND PREFERENCES}

\section{IN \\ LANDSCAPING}

Northeast Regional Research Publication

by

The Technical Committee of the Northeast Regional Research Project, N.E.M.-15, Market Development for Ornamental Nursery Products

\section{Administrative Advisers}

Ordway Starnes Joseph F. Metz, Jr.
New Jersey Agr. Exp. Sta. Cornell University Agr. Exp. Sta.

\section{Research Committee Members}

Elmar Jarvesoo

Lawrence Dougherty

Ronald Gatty

Joseph F. Metz, Jr. (until 1960)

Dana Goodrich

Clare Becker

Harrison Flint

Roger W. Pease
Massachusetts Agr. Exp. Sta. New Hampshire Agr. Exp. Sta. New Jersey Agr. Exp. Sta. Cornell University Agr. Exp. Sta. Cornell University Agr. Exp. Sta. Pennsylvania Agr. Exp. Sta. Rhode Island Agr. Exp. Sta. West Virginia Agr. Exp. Sta.

\section{Cooperating U.S.D.A. Members}

Lloyd Halvorson S.E.S.D.

Roscoe Saville S.E.S.D.

Loyd Martin A.M.S.

Alden Manchester A.M.S. 


\section{CONTENTS}

Page

FOREWORD

$\mathrm{v}$

INFERENCES AND CONCLUSIONS ___ 1

INTRODUCTION _-____ 5

PURCHASES: - 5

Plants Purchased and Channels of Purchase _-_ 5

SUPPLIES PURCHASED -._- 9

VALUE OF PURCHASES _-____ 9

SEASON OF PURCHASE ___________ 10

Past, Present, and Future Purchases ___________ 11

SERVICES RELATED TO PURCHASES: _.____ 12

Delivery and Planting ___ 12

Guarantees, Replacements, and Overgrown Plants _._. 13

LANDSCAPE SERVICES _-_ 15

FACTORS RELATED TO PURCHASES: 16

FAMILY INCOME - 16

Age of House and Length of Occupancy _-___ 18

DRAWN LANDSCAPE PlaNS ___________ 21

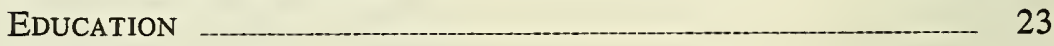

PROPERTY VALUE _-___ 24

Size LaNDSCAPE AREA _-_ 26

URBANIZATION OF RESIDENCE ______ 26

REMODELING _-_ 28

CONSUMER WANTS, PREFERENCES, AND ATTITUDES: _._._ 28

Plant Preferences _-_ 28

Attitudes Toward Further Plantings ___ 31

DESIRE FOR INFORMATION _- 32

Attitudes Toward Nursery and Chain Store

PURCHASING OF TREES AND SHRUBS ___ 33

ATTITUDES TOWARD LANDSCAPING 35 


\section{FOREWORD}

This report is a Northeast regional publication. It is based on a cooperative study which was part of the Northeast Regional Project, N.E.M.-15, Market Development for Ornamental Nursery Products. The agricultural experiment stations of Massachusetts, New Hampshire, New Jersey, New York, Pennsylvania, Rhode Island, and West Virginia cooperated in obtaining the data used. Primary responsibility for the questionnaire was delegated to Pennsylvania; primary responsibility for the sampling technique and for tabulation of results was delegated to New Jersey; and primary responsibility for the preparation of a manuscript was delegated to West Virginia. The study was financed in part by the Regional Research Fund, Hatch Act, as amended August $11,1955$. 



\section{Inferences and Conclusions}

\section{NEED FOR INFORMATION}

In the Northeast Region about one homeowner in three is unable to name specifically a favorite plant for foundation planting. About one-half feel a need for more information, and two-fifths of these believe that by supplying information, nurserymen could best improve their services. Mimeographed pamphlets might be prepared and distributed as part of an effort toward information service. A series of such pamphlets might discuss the most common ornamental plants, planting, care, mulching, fertilizing, pruning, insect and disease control. Illustrations would be useful. Pamphlets prepared by a nurseryman and bearing his name might procure more good will than commercially prepared material. The Agricultural Extension Service could be especially effective in supplying homeowners with information about the care and use of trees and shrubs.

\section{FAMILY INCOME}

Between $\$ 4,000$ and $\$ 8,000$, family income has little effect upon the number of purchases homeowners make or upon the dollar value of purchases. However, between the extremes of income (less than $\$ 2,000$ and $\$ 10,000$ or more), the rate of purchasing is doubled, and the amount spent per purchase increases fifteen fold. About one-eighth of the homeowners in the Northeast have family incomes of less than $\$ 4,000$, but they make only about 3 percent of the plant purchases. Nurserymen might help sales by specializing in services to low-income owners and providing them with low-priced, loosely sheared, rapidly grown ornamentals.

\section{DRAWN LANDSCAPE PLANS}

The possession of drawn landscape plans is closely associated with relatively large expenditures for trees and shrubs, and also with relatively large family incomes. However, it is difficult for nurserymen to gauge a homeowner's income. By specializing in gratuitous landscape consultation and perhaps in landscape sketches, nurserymen might increase sales.

\section{AGE OF HOUSE}

In the Northeast, owners of homes less than five years old purchase trees and shrubs about twice as often as other owners, and their purchases average about twice the dollar value of purchases by other owners. Therefore, the demand for trees and shrubs may be expected to expand during periods when the construction of homes is booming. However, during periods when house construction lags, nurserymen might maintain or expand their business by fostering repeat and replacement buying among established homeowners. 


\section{LANDSCAPE AND MAINTENANCE SERVICES}

Homeowners in the Northeast usually hire more landscape services as their family incomes increase. However, relatively more owners whose family incomes are less than $\$ 2,000$ hire handyman (unskilled) services than owners whose incomes range from $\$ 2,000$ to $\$ 8,000$. About fourfifths of these low-income owners are more than 60 years old, possibly no longer physically able to care for their lawns and shrubbery. Nurserymen, by performing services for these owners, might increase good will in the entire neighborhood and thus might increase sales among neighbors.

Past services reported by homeowners are predominantly planting services; those planned for the future are predominantly caretaking. However, the same numbers of homeowners plan future services as hired past services (about one in four). The stated intention to shift from planting to caretaking services may be, in part, wishful thinking in that it expresses a hope that present landscape plantings will be adequate. However, stated intentions also indicate that future services hired will about parallel past services hired.

\section{DELIVERY}

Nurserymen make no charge for about three-fifths of their deliveries to retail purchasers, even for distances of 30 miles and more. Yet customers carry home three-quarters of all the purchases made. The do-it-yourself trend in landscaping may be expected to increase as the work week decreases. Garden centers are especially suited to serve the do-it-yourself clientele. Nurserymen who have added garden centers or specialized sales lots to their operations discriminate against the cash-andcarry, do-it-yourself customers if they maintain plant prices which include delivery. Unless cash-and-carry customers are offered some price advantage, or unless a definite charge for delivery is made, the do-it-yourself, cash-and-carry patrons will tend to seek lower prices.

\section{URBANIZATION OF RESIDENCES}

Rural nonfarm residents make about one-twelfth of the Region's purchases of trees and shrubs. Delivery of three-tenths of these purchases is by mail, but delivery by mail composes only about one-eighth of the urban and suburban tree-and-shrub purchases in the Northeast. Evidently rural nonfarm residents order by mail because they lack the direct services of nurserymen. Small, nonurban cities, towns, and villages offer opportunities for non-mail-order nurseries to expand sales.

\section{PAST AND FUTURE PURCHASES}

Homeowners who have spent the most on ornamentals since occupying their homes plan to spend the most during the next three-year period; 
and homeowners who have spent the most very recently have spent the most since occupying their homes. Thus satisfactory plant performance and customer good will are especially important in a highly competitive market or during periods of slack home building.

\section{CHAIN STORE AND NURSERY SALES}

About one-tenth of the trees and shrubs sold in the Northeast are purchased direct from chain stores or chain store garden centers. However, exclusive of roses, chain stores sell only about one-twentieth of all the plants purchased-about the same number as independent stores and less than one-tenth as many as are purchased direct from nurseries. Independent stores sell relatively more balled-and-burlapped stock than chain stores, probably procuring many of their trees and shrubs locally.

Unless the shipping advantage possessed by local growers of relatively heavy, bulky, balled-and-burlapped stock is reduced, chain stores probably will continue as minor competitors in marketing such balled-and-burlapped plants as evergreen shrubs and evergreen trees.

Patronage of chain stores for trees and shrubs is not centered in any particular income group but is distributed among all income brackets. Convenience and impulse buying probably are determining factors in chain store purchases of ornamentals.

About one homeowner in two shows a favorable attitude toward purchasing trees and shrubs at nurseries, and about one in three is favorably inclined toward purchasing at chain stores. The present seven-toone ratio of ornamentals sold at nurseries and at chain stores does not reflect these attitudes. If in the future, chain stores offer the plants customers desire at competitive prices, and if present attitudes continue, the relative volume purchased at chain stores will probably increase. However, if nurserymen succeed in increasing good will among homeowners, present attitudes may shift, and any trend toward equalization of sales might be correspondingly halted.

\section{ROSES}

The trade in rose plants in the Northeast is relatively large. The data analyzed indicate that enough were sold in the Region during 1958 to supply about three-quarters of all the homeowners with one rose bush apiece (exclusive of owners whose homes had less than 200 square feet of lawn area or an estimated value of less than $\$ 10,000$ ).

Roses usually are sold in a bare-rooted condition. They therefore are relatively light in weight, are easy to pack and handle, and are especially suited to shipping and chain store marketing. Local nurserymen do not have the marketing advantage in roses that they have in the heavier, difficult to handle balled-and-burlapped plants. Therefore 
increasing competition may be expected in the Northeast from non-Regional rose growers situated in areas which have a comparative advantage in production-usually in the form of climate, soil, topography, or labor costs.

\section{THE TREND TOWARD YEWS}

The evergreen shrubs purchased in the Northeast exceed the deciduous shrubs (except roses) by a ratio of about nine-to-five; and yews compose about one-third of all the evergreen shrubs purchased. However, the stated preference for yews exceeds even the rate at which they are purchased. Yews are named by homeowners as their favorite foundation plant as often as azaleas (evergreen plus deciduous), junipers, arbor-vitae, and rhododendron combined. About 40 percent of all the plants specifically named as foundation plant favorites are yews.

Since preference exceeds practice in the case of yews, the trend toward their purchase probably will increase, especially if nurserymen demonstrate to homeowners that yews more than compensate for the extra initial cost entailed. Stated preferences indicate that yews give more satisfaction than any other foundation plant. Therefore, a high percentage of yew sales should stimulate good will and hence future patronage.

\section{THE TREND AWAY FROM JUNIPERS AND ARBOR-VITAE}

The Region's homeowners purchase yews in preference to arbor-vitae and junipers at ratios of about five-to-two and eight-to-five, respectively; and fruit trees are the only ornamental plants which homeowners name as less satisfactory than junipers and arbor-vitae. The trend toward purchasing yews instead of arbor-vitae and junipers probably will accelerate, and nurserymen may find homeowners receptive to attractive offers for replacing junipers and arbor-vitae with yews or other more suitable shrubs.

\section{OVERGROWN SHRUBS AND MISPLACED TREES}

About three-quarters of the Region's home plantings apparently are mature or over-age. Such plantings tend to be overgrown, and overgrown plants often obstruct passageways and obscure windows. Only about onetenth of the replacements made by homeowners in the Northeast are for overgrown plants. Probably the replacement of overgrown shrubbery and misplaced shade trees offers an opportunity for nurserymen to expand sales. A skillful informative campaign might create a substantial demand for replacements. 


\section{Introduction}

N 1959 the agricultural experiment stations of seven states' in the Northeast Region surveyed the area to determine purchasing patterns and preferences involved in landscaping homes. Information was obtained about type, number, and dollar value of the plants purchased; about channels through which purchases were made; about seasonal characteristics of purchasing; and about delivery, guarantee, replacement, and the performance of services. Information also was obtained about family income, house age, length of occupancy, property value, size of landscape area, degree of urbanization, education, plans for future buying, possession of drawn landscape plans, and house remodeling. Various attitudes and preferences were ascertained.

A probability sample ${ }^{2}$ was drawn to represent all of the Region's twelve states. Interviews were restricted to detached, nonfarm, singlefamily, owner-occupied homes with estimated values of at least $\$ 10,000$ and with some landscaping evidenced on areas comprising at least 200 square feet. The sample yielded 1,445 completed questionnaires-730 from suburban areas, 549 from urban areas, 158 from rural areas, and 8 from indeterminate areas. The period for interviewing extended from July to November, inclusive, although about 40 percent of the schedules were completed in August.

\section{Purchases}

\section{PLANTS PURCHASED AND CHANNELS OF PURCHASE}

About one-quarter of the homeowners interviewed reported that they had made at least one purchase of ornamental trees or shrubs between July 1,1958 , and July $1,1959 .^{3}$ Some made more than one purchase during the year. In Table 1 the plants purchased are classified according to six plant groups.

More roses than any other plant class were purchased, but the difference between the numbers of roses and of evergreen shrubs was not statistically significant. ${ }^{4}$ In Tables 2 and 3 the channels of purchase are

\footnotetext{
1 Massachusetts, New Hampshire, New Jersey, New York, Pennsylvania, Rhode Island, West Virginia.

2 Ronald Gatty and Kenneth Hamje, The Use of Housing M.C.D. Data and Sanborn Maps for an Area Probability Sample of Homeowners. Agri. Exp. Sta., Rutgers University, Technical A.E. No. 3, Jan. 1961.

3 Designated as 1958 purchases throughout this publication.

4 Throughout the analyses of data, relationships were tested by Chi Square. To facilitate clarity of expression, relationships significant on at least the 5 percent level are designated, in the text only, by *. In other words, relationships so designated would have happened by chance less than one time in twenty.
} 
Table 1. Plants Purchased (Respondents in the Northeast Region. July 1, 1958-June 30, 1959)

\begin{tabular}{l|c}
\hline \multicolumn{1}{c|}{ Class of Plant } & Plants Purchased \\
\hline & Percent \\
\hline Roses & 33 \\
Evergreen Shrubs & 30 \\
Evergreen Trees & 10 \\
Deciduous Shrubs* & 16 \\
Deciduous Shade Trees & 4 \\
Deciduous Flowering Trees & 7 \\
Total & 100 \\
$\quad$ Number & 3,364 \\
\hline
\end{tabular}

*Exclusive of Roses.

Table 2. Channels of Purchase (Channels of purchase, distributed by classes of plant. Respondents in the Northeast Region. July 1, 1958-June 30, 1959)

\begin{tabular}{l|c|c|c|c|c|c}
\hline \hline \multirow{2}{*}{ Class of Plant } & \multicolumn{6}{|c}{ Channels of Purchase* } \\
\cline { 2 - 7 } & $\begin{array}{c}\text { Direct } \\
\text { From } \\
\text { Chain } \\
\text { Store }\end{array}$ & $\begin{array}{c}\text { Direct } \\
\text { From } \\
\text { Independ- } \\
\text { ent Store }\end{array}$ & $\begin{array}{c}\text { Direct } \\
\text { From } \\
\text { Nursery }\end{array}$ & $\begin{array}{c}\text { By } \\
\text { Mail } \\
\text { Order }\end{array}$ & $\begin{array}{c}\text { Through } \\
\text { Agent }\end{array}$ & Other \\
\hline \multirow{2}{*}{ Roses } & Percent & Percent & Percent & Percent & Percent & Percent \\
\cline { 2 - 7 } Evergreen Shrubs & 55 & 37 & 26 & 65 & 11 & 4 \\
Evergreen Trees & 16 & 32 & 36 & 9 & 26 & 42 \\
Deciduous Shrubs & $0^{* *}$ & 15 & 10 & 2 & 50 & 21 \\
Deciduous Flowering Trees & 21 & 7 & 17 & 11 & 11 & 21 \\
Deciduous Shade Trees & 5 & 5 & 7 & 9 & 1 & 8 \\
Total S-- & 3 & 4 & 4 & 4 & 1 & 4 \\
$\quad$ Number*** & 100 & 100 & 100 & 100 & 100 & 100 \\
\hline
\end{tabular}

*It was difficult for respondents to differentiate accurately among nursery garden centers, chain store garden centers, independent garden centers, nurseries, and roadside stands. Therefore nursery garden centers were listed under nurseries, chain store garden centers under chain stores, and roadside stands under others. Thus the category Independent Stores includes independent garden centers.

**Less than $1 / 2$ of 1 percent.

***There were 27 non-respondents for roses and 10 for deciduous shrubs. As indicated in Table 1 , the actual number of plants purchased was 3,364 .

distributed by classes of plant, and the classes of plant are distributed by channels of purchase. About half of all the trees and shrubs purchased at chain stores ${ }^{5}$ were roses. Roses also comprised about two-thirds of the plants purchased by mail.

Roses are especially adapted to shipment and storage in a bare-rooted condition. Bare-rooted plants are relatively light in weight, and barerooted roses are less bulky than most other ornamental trees and shrubs. This adaptability to long-distance shipping may indicate that an increasing portion of the Northeast's rose demand may be supplied from areas where production is at a comparative advantage.

$5 \mathrm{~A}$ chain store was defined as a concern with three or more separate stores, all under the same name. 
Table 3. Channels of Purchase (Classes of plant distributed by channels of purchase. Respondents in the Northeast Region.

July 1, 1958-June 30, 1959)

\begin{tabular}{|c|c|c|c|c|c|c|c|}
\hline \multirow[b]{2}{*}{$\begin{array}{c}\text { Channels } \\
\text { of } \\
\text { Purchase }\end{array}$} & \multicolumn{7}{|c|}{ Class of Plant } \\
\hline & Roses & $\begin{array}{c}\text { Ever- } \\
\text { green } \\
\text { Shrubs }\end{array}$ & $\begin{array}{l}\text { Ever- } \\
\text { green } \\
\text { Trees }\end{array}$ & $\begin{array}{l}\text { Decidu- } \\
\text { ous } \\
\text { Shrubs }\end{array}$ & $\begin{array}{c}\text { Decldu- } \\
\text { ous } \\
\text { Flowering } \\
\text { Trees }\end{array}$ & $\begin{array}{c}\text { Decldu- } \\
\text { ous } \\
\text { Shade } \\
\text { Trees }\end{array}$ & $\begin{array}{c}\text { All } \\
\text { Plants }\end{array}$ \\
\hline & Percent & Percent & Percent & Percent & Percent & Percent & Percent \\
\hline $\begin{array}{l}\text { Direct from } \\
\text { Chain Store }\end{array}$ & 14 & 4 & $0^{*}$ & 11 & 6 & 8 & 9 \\
\hline $\begin{array}{l}\text { Direct from } \\
\text { lndependent Store .. }\end{array}$ & 4 & 4 & 6 & 2 & 3 & 4 & 4 \\
\hline Nursery & 54 & 79 & 63 & 71 & 69 & 69 & 67 \\
\hline By Mail Order & 26 & 4 & 2 & 9 & 17 & 13 & 13 \\
\hline Through Agent & 2 & 4 & 22 & 3 & 1 & 2 & 4 \\
\hline Other & $0^{*}$ & 5 & 7 & 4 & 4 & 4 & 3 \\
\hline Total ___ & 100 & 100 & 100 & 100 & 100 & 100 & 100 \\
\hline Number & 1,087 & 1,001 & 342 & 546 & 232 & 119 & $3,327^{* *}$ \\
\hline
\end{tabular}

* Less than $1 / 2$ of 1 percent.

**There were 37 non-responses. The actual number of plants purchased was 3,364 .

Evergreen trees made up a relatively small proportion of the plants purchased through every channel except agents (door-to-door salesmen), * half of whose sales were evergreen trees (Table 2). Respondents may have included nursery landscapers as agents; and landscapers, by the nature of their profession, sell a relatively large number of plants when they service a piece of property. Their services probably are in especial demand among owners of extensive lawns and pretentious houses. Owners of such properties probably use more evergreen trees than owners of modest homes and small properties. Table 4 shows that about one-third of the evergreen shrubs were yews, and that yews exceeded all broadleaved evergreen shrubs combined.*

Table 5 classifies the purchases which included ground covers or climbers, according to the channels through which the purchases were made. Only 2 percent of the purchases included ground covers or climbers, and data concerning their dollar value were insufficient to serve as a basis for analysis. Apparently only a limited demand for ground covers and climbers exists in the Northeast.

Respondents were asked to list the length of hedges they planted in 1958 and also to list through what channels the plants had been purchased (Table 6). If the plants were spaced at 18 inches, respondents used for hedges only about one-tenth of all the plants they purchased.

*Significant. 
Table 4. Evergreen Shrubs Purchased (Respondents in the Northeast Region. July 1, 1958-June 30, 1959)

\begin{tabular}{l|c}
\hline \multicolumn{1}{c|}{ Class of Shrub } & Shrubs Purchased \\
\hline & Percent \\
Yews & 32 \\
Junipers & 19 \\
Arbor-vitae & 13 \\
Unidentified Broad-Leaved Evergreen Shrubs & 27 \\
Unidentified Narrow-Leaved Evergreen Shurbs & 9 \\
Total Number & 100 \\
$\quad$ & 1,001 \\
\hline
\end{tabular}

Table 5. Ground Covers, Climbers, and Other Purchases (Purchases of ground covers and climbers distributed by channels of purchase. Respondents in the Northeast Region. July 1, 1958-June 30, 1959)

\begin{tabular}{l|c|c|c}
\hline \multirow{2}{*}{ Channels of Purchase } & \multicolumn{3}{|c}{ Number of Purchases } \\
\cline { 2 - 4 } & $\begin{array}{c}\text { Ground Covers } \\
\text { or Climbers }\end{array}$ & $\begin{array}{c}\text { Other Plant } \\
\text { Classes }\end{array}$ & All Classes \\
\hline \multirow{3}{*}{ Direct from Nursery } & Percent & Percent & Percent \\
\cline { 2 - 4 } Direct from Chain Store & 1 & 60 & 61 \\
Direct from Independent Store & 1 & 14 & 15 \\
Through Agent & None & 4 & 4 \\
By Mail Order & None & 2 & 2 \\
Other & None & 13 & 13 \\
Total None & 2 & 5 & 5 \\
Number & - & 98 & 100 \\
\hline
\end{tabular}

*Respondents did not report whether or not ground covers and climbers were included in two purchases. These two purchases are not included in this table.

\section{Table 6. Hedges Purchased Through Various Channels (Respondents} in the Northeast Region. July 1, 1958-June 30, 1959)

\begin{tabular}{l|c}
\hline \hline \multicolumn{1}{c|}{ Channels of Purchase } & Amounts Purchased* \\
\hline & Percent \\
Direct from Nursery & 60 \\
By Mail Order & 40 \\
Direct from Chain Store & - \\
Direct from Independent Store & - \\
Through Agent & - \\
Other & - \\
Total & 100 \\
Yards & 189 \\
\hline
\end{tabular}

*Percentages represent proportions of the total length of hedges planted. Data were not available concerning the plant classes used for hedges. Therefore the totals in this table were not included in tabulations of the number of plants purchased.

Only two channels were used for procuring hedge plants-direct nursery sales ( 60 percent) and mail order purchasing (40 percent). Evidently the demand for hedges in the Northeast is relatively small. 
All but 16 percent of the trees and shrubs purchased from chain stores were deciduous (Table 2), but only about half of the ornamentals purchased from independent stores were deciduous. This difference between chain store and independent store purchases might be explained by different procurement practices. Balled-and-burlapped evergreen trees are the most bulky of any plant class and therefore the least suited to long-distance shipping. Chain stores may tend to sell bare-rooted deciduous ornamentals because they can be shipped conveniently from considerable distances, but independent stores may concentrate on the heavier and more bulky balled-and-burlapped evergreens which may be procured locally.

Total chain store sales were only about one-tenth of all the trees and shrubs purchased; about seven times as many ornamentals were purchased direct at nurseries as at chain stores; and mail order purchases exceeded chain store purchases by about 50 percent.* So long as evergreens are packed balled-and-burlapped and remain more popular than deciduous trees and shrubs (except roses), sales of ornamentals at mass markets may continue to be relatively small.

\section{SUPPLIES PURCHASED}

Data not tabulated in this report indicate that orders for garden supplies were included with approximately one-tenth of the purchases of plants. The total value of the garden supplies was about one-twentieth of the reported value of the plants purchased. These data report only the purchases of garden supplies which were included in plant orders; possibly they represent a relatively small proportion of the total garden supply purchases made by the respondents involved.

\section{VALUE OF PURCHASES}

Table 7 shows that purchases from chain stores are even less important than Table 3 indicated. On the basis of plant numbers, the ratio of chain store purchases to non-chain store purchases was about one-toten (Table 3 ), but on the basis of dollar value the ratio dropped to about one to twenty.

The total value of direct nursery sales of trees and shrubs was more than twice as large as the value of purchases through all other channels, about nine times as large as all mail order purchases, and about fourteen times as large as all chain store purchases.* Although only 2 percent of the purchases were made from agents soliciting orders, the per-purchase value was so high $(\$ 154.75)$ that the total value was larger than the value of purchases from any other channel except direct from nurseries.*

*Significant. 
Table 7. Value of Purchases (Dollar value of purchases, distributed by channels of purchase. Respondents in the Northeast Region.

July 1, 1958-June 30, 1959)

\begin{tabular}{l|c|c|c}
\hline Channels of Purchase & $\begin{array}{c}\text { Number of } \\
\text { Purchases }\end{array}$ & $\begin{array}{c}\text { Average } \\
\text { Value }\end{array}$ & $\begin{array}{c}\text { Total } \\
\text { Value }\end{array}$ \\
\hline & Percent & Dollars & Percent \\
Direct from Nursery & 60 & 34.19 & 70 \\
Through Agent & 2 & 154.75 & 9 \\
By Mail Order & 13 & 18.84 & 8 \\
Direct from Chain Store & 15 & 10.70 & 5 \\
Direct from Independent Store & 5 & 29.62 & 5 \\
Other & 5 & 17.70 & 3 \\
Not Recorded & $0 *$ & 3.00 & $0^{*}$ \\
All Channels & 100 & 29.71 & 100 \\
Number & $458^{* *}$ & & \\
\hline
\end{tabular}

*Less than $1 / 2$ of 1 percent.

**There were 458 purchases of known amounts and 41 of unknown amounts. The 41 purchases of unknown amounts are omitted from this table.

\section{SEASON OF PURCHASE}

Data not listed in table form show that about one-half of the total length of hedges was planted with ornamentals purchased in the fall (Table 8). This almost equal relationship between fall and spring purchasing is in sharp contrast to the usual relationship* (Table 8). In each plant class a much larger proportion of plants was purchased in the spring

Table 8. Ornamentals Purchased in the Spring and Fall (Respondents in the Northeast Region. July 1, 1958-June 30, 1959)

\begin{tabular}{l|c|c|c}
\hline \multirow{2}{*}{ Class of Plant } & \multicolumn{3}{|c}{ Purchases } \\
\cline { 2 - 4 } & Spring & Fall & Total \\
\hline & Percent & Percent & Percent \\
\cline { 2 - 4 } Roses & 86 & 14 & 100 \\
Evergreen Shrubs & 63 & 37 & 100 \\
Evergreen Trees & 65 & 35 & 100 \\
Deciduous Shrubs & 78 & 22 & 100 \\
Deciduous Shade Trees & 81 & 19 & 100 \\
Deciduous Flowering Trees & 77 & 23 & 100 \\
All Classes & 75 & 25 & 100 \\
Number & 2,484 & 843 & $3,327^{*}$ \\
\hline
\end{tabular}

*Respondents were unable to classify 37 plants by season of purchase-10 deciduous shrubs and 27 roses. These 37 plants are not included in the table.

than in the fall.* Roses showed the greatest proportion of spring purchases, a ratio of about six to one between spring and fall.*

Table 9 shows the channels through which spring and fall purchases of ornamentals were made. The proportions of fall and spring sales varied only slightly among channels except in the case of chain stores, where

*Significant. 
Table 9. Channels of Spring and Fall Purchases (Respondents in the Northeast Region. July 1, 1958-June 30, 1959)

\begin{tabular}{l|c|c|c}
\hline \hline \multirow{2}{*}{ Channel of Purchase } & \multicolumn{3}{|c}{ Plants Purchased } \\
\cline { 2 - 4 } & Spring & Fall & Total \\
\hline & Percent & Percent & Percent \\
\cline { 2 - 4 } Direct from Nursery & 71 & 29 & 100 \\
Direct from Chain Store & 94 & 6 & 100 \\
Direct from Independent Store & 74 & 26 & 100 \\
By Mail Order & 73 & 27 & 100 \\
Through Agent & 100 & $0 *$ & 100 \\
Other & 62 & 38 & 100 \\
All Channels & 75 & 25 & 100 \\
Number & 2,484 & 843 & $3,327^{* *}$ \\
\hline
\end{tabular}

*Less than $1 / 2$ of 1 percent.

* No responses were recorded for 37 plants-10 deciduous shrubs and 27 roses.

only 6 percent of all purchases were made in the fall-a much smaller proportion than through any other channel.* Probably the relatively large number of roses sold by chain stores reduced the proportion of fall sales.

\section{PAST, PRESENT, AND FUTURE PURCHASES}

Table 10 indicates the relationship between past expenditures for trees and shrubs and expenditures planned for the next three-year period. In general, the respondents who had spent most in the past, planned to spend most in the future. Data not listed in table form show that about 40 percent of the homeowners intended to make future plantings; and that about 85 percent of the respondents who planned definite expenditures had purchased in the past. The analysis indicates that in an area without new housing developments, repeat customers comprise much of the current business.

Table 10. Past and Future Expenditures (Respondents' tree-and-shrub expenditures since occupying their homes, and expenditures for trees and shrubs planned for the next three years. Northeast Region. 1959)

\begin{tabular}{l|c|c|c|c|c|c}
\hline \hline \multirow{2}{*}{$\begin{array}{c}\text { Total Spent Since Occupancy } \\
\text { (Dollars) }\end{array}$} & \multicolumn{6}{|c}{ Respondents Planning to Spend: } \\
\cline { 2 - 7 } & $\begin{array}{c}\text { Less } \\
\text { Than }\end{array}$ & $\begin{array}{c}\$ 50- \\
\$ 299\end{array}$ & $\begin{array}{c}\$ 300 \\
\text { or } \\
\text { More }\end{array}$ & $\begin{array}{c}\text { Amount } \\
\text { Not } \\
\text { Decided }\end{array}$ & \multicolumn{2}{|c}{ Total } \\
\hline & Percent & Percent & Percent & Percent & Percent & Number \\
\cline { 2 - 7 } Don't Know or Nothing & 32 & 33 & 4 & 31 & 100 & 107 \\
Less than 100 & 47 & 32 & 4 & 17 & 100 & 302 \\
$100-299$ & 28 & 59 & 2 & 11 & 100 & 107 \\
300 or More & 5 & 62 & 16 & 17 & 100 & 58 \\
All Who Planned to Spend & 36 & 40 & 5 & 19 & 100 & $574^{*}$ \\
\hline
\end{tabular}

*Among the 1,445 respondents, 871 did not express a definite intention to make more plantings.

*Significant. 
Table 11 shows the relationship between recent and since-occupancy expenditures for trees and shrubs. The data indicate that homeowners who spend the most during their entire term of tenure also make the largest current purchases. The average 1958 expenditures increased about 30 -fold as past expenditures increased from less than $\$ 100$ to $\$ 1000$ or more.*

Table 11. Past and Recent Expenditures (Respondents' tree-and-shrub expenditures since occupying their homes, and recent expenditures. Northeast Region. July 1, 1958-June 30, 1959)

\begin{tabular}{l|c|c|c}
\hline \hline \multirow{2}{*}{\begin{tabular}{c} 
Past $\begin{array}{c}\text { Expenditures } \\
\text { (Dollars) }\end{array}$ \\
\cline { 3 - 4 }
\end{tabular}} & Respondents & $\begin{array}{c}\text { 1958 Purchases } \\
\text { Amouge }\end{array}$ & $\begin{array}{c}\text { Proportion of } \\
\text { Total Value }\end{array}$ \\
\hline & Percent & Dollars & Percent \\
\cline { 3 - 4 } Less than 25 & 28 & 2.38 & 14 \\
$25-99$ & 32 & 6.56 & 36 \\
$100-199$ & 17 & 10.25 & 19 \\
$200-299$ & 9 & 19.51 & 13 \\
$300-499$ & 7 & 23.45 & 10 \\
$500-999$ & 4 & 40.53 & 4 \\
1,000 or More & 3 & 64.50 & 4 \\
All Classes & 100 & 11.45 & 100 \\
Number & $1,183^{*}$ & & $487^{*}$ \\
\hline
\end{tabular}

*Among the 1,193 respondents who had made past purchases, 10 did not estimate the amounts. They also made 12 purchases in 1958 , amounting to $\$ 84$.

\section{Services Relafed to Purchases}

\section{DELIVERY AND PLANTING}

About three-quarters of the 1958 purchases were carried home by customers (Table 12). Within a distance of five miles, about nine-tenths of the deliveries by the seller were "free of charge" in that no specific delivery charge was made. Apparently, customers who carried home their purchases paid the same price as customers who received "free" delivery. Except for the comparatively large proportion of free delivery within five miles, no-charge delivery did not decrease as delivery distance increased.

In contrast to the comparative frequency of no-charge deliveries, planting charges were included in the price of plants in about one case in ten (Table 13). Within distances of thirty miles, distance of delivery apparently did not affect the inclusion of planting costs, for within this distance range the proportion of no-charge planting service varied only from about 9 to 11 percent.

*Significant. 
Table 12. Delivery Methods, Distances, and Charges (Purchases of trees and shrubs by respondents in the Northeast Region. July 1, 1958-June 30, 1959)

\begin{tabular}{l|c|c|c|c}
\hline \multirow{2}{*}{$\begin{array}{c}\text { Distance } \\
\text { (Miles) }\end{array}$} & \multicolumn{4}{|c}{ Purchases } \\
\cline { 2 - 5 } & \multicolumn{2}{|c|}{ Delivered by Seller } & $\begin{array}{c}\text { Carried } \\
\text { Home } \\
\text { By Buyer }\end{array}$ & Total \\
\cline { 2 - 5 } & No Charge & Charge & Number & Number \\
\cline { 2 - 5 } & Number & Number & & 245 \\
\hline $0-5$ & 36 & 3 & 206 & 82 \\
$6-10$ & 9 & 6 & 67 & 28 \\
$11-20$ & 4 & 1 & 23 & 15 \\
$21-30$ & 1 & 1 & 13 & 29 \\
More than 30 & 5 & 1 & 23 & $399^{*}$ \\
All Classes & 55 & 12 & 332 &
\end{tabular}

* Not recorded in this table are $\mathbf{7 7}$ mail order purchases, 5 purchases carried home for unknown distances, and 18 purchases for which details of delivery were not specified.

Table 13. The Inclusion of Planting Service in Plant Price (The inclusion of planting services in the price paid for trees and shrubs, distributed by delivery distance. Respondents in the Northeast Region. July 1, 1958-June 30, 1959)

\begin{tabular}{l|c|c|c|c}
\hline \hline \multirow{2}{*}{\begin{tabular}{c} 
Delivery $\begin{array}{c}\text { Distance } \\
\text { (Miles) }\end{array}$ \\
\cline { 2 - 5 }
\end{tabular}} & $\begin{array}{c}\text { Planting Service: } \\
\text { Included } \\
\text { In Price }\end{array}$ & $\begin{array}{c}\text { Not Included } \\
\text { In Price }\end{array}$ & \multicolumn{2}{c}{ Total } \\
\hline & Percent & Percent & Percent & Number \\
\cline { 2 - 5 } $0-5$ & 9 & 91 & 100 & 243 \\
$6-10$ & 11 & 89 & 100 & 83 \\
$11-20$ & 9 & 91 & 100 & 34 \\
$21-30$ & 11 & 89 & 100 & 18 \\
More than 30 & 7 & 93 & 100 & 44 \\
All Classes & 9 & 91 & 100 & 422 \\
\hline
\end{tabular}

*Not included in the table are 77 mail order purchases.

\section{GUARANTEES, REPLACEMENTS, AND OVERGROWN PLANTS}

Table 14 lists various data pertinent to the replacement and guarantee of trees and shrubs. About one-half of the respondents who had purchased any plants since occupying their homes reported that at least one of the plants had died. About three-fifths of the dead plants had been guaranteed, but replacement for these had been requested only about three-fifths of the time. However, when respondents had requested replacement of a guaranteed plant, the request had been granted almost nine-tenths of the time. Evidently homeowners tend to request replacement of guaranteed plants much less often than sellers honor their guarantees.* However, guarantees may have expired before some of the plants died. Therefore, replacements would not have been requested in these cases.

* Significant 
Table 14. Selected Responses About Replacements of Trees and Shrubs (Respondents in the Northeast Region. 1959)

\begin{tabular}{l|c}
\hline \multicolumn{1}{c|}{ Respondents Who: } & $\begin{array}{c}\text { Proportion of Each Item } \\
\text { to } \begin{array}{c}\text { Ene Preceding Item } \\
\text { the }\end{array}\end{array}$ \\
\hline Were Interviewed* Percent \\
Had made Plantings & 100 \\
Reported the Death of at Least One Purchased Plant & 83 \\
Reported that the Dead Plant had been Guaranteed & 50 \\
Had Requested a Replacement for the Dead, Guaranteed Plant & 60 \\
Had Received the Replacement Requested - & 56 \\
Had Paid Nothing for Replacement - & 86 \\
\hline
\end{tabular}

*Total interviewed-1,445.

Four reasons for making replacements were given often more than any others (Table 15). Dead or Dying Plant was listed more often than all other reasons combined, but Overgrown Plant was listed only about one-twentieth of the time.

Table 16 shows that about three-quarters of the plantings inspected were composed of mature and over-age plants. Such plants often are overgrown. Apparently nurserymen are not influencing homeowners to replace overgrown or misplaced plants which are obstructing walkways, windows, and doors.

Table 15. Reasons Given for Replacing Ornamental Trees and Shrubs (Respondents in the Northeast Region. 1959)

\begin{tabular}{l|c}
\hline \multicolumn{1}{c|}{ Reasons for Replacement } & Respondents \\
\hline & Percent \\
Dead or Dying Plant & 57 \\
Unattractive Plant & 17 \\
Unsuitable Plant & 13 \\
Overgrown Plant & 5 \\
Other & 8 \\
Total Number & 100 \\
Number & $462^{*}$ \\
\hline
\end{tabular}

*The reasons for replacements made were not recorded by 18 respondents.

Table 16. The Growth Stage of Plantings as Estimated by Interviewers (Respondents in the Northeast Region. 1959)

\begin{tabular}{|c|c|}
\hline Age of Plantings & Plantings \\
\hline & Percent \\
\hline Young 드 & 27 \\
\hline \multirow{2}{*}{ 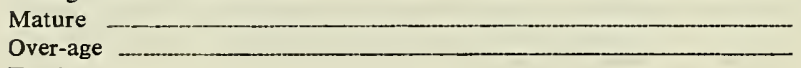 } & 61 \\
\hline & 12 \\
\hline Total & 100 \\
\hline Number & $1,419 *$ \\
\hline
\end{tabular}

The age of plantings was not recorded for 26 among the 1,445 respondents. 
Table 17 shows that about 31 percent of the services hired in the past were planting services, but that only 20 percent of the respondents planned to hire planting services in the future.* On the other hand, only about 19 percent of the past services had been specialist caretaking, but 27 percent of the respondents planned to hire specialist caretaking in the future.* Possibly many respondents who had hired services to establish their plantings planned to hire future services to care for the plantings already established. The total numbers in the table (546 and 366 ) seem to indicate that more services had been hired than would be hired. However, only 365 respondents had hired the 546 past services, some hiring several kinds. The 366 respondents who desired future services also might be expected to hire several kinds thus raising the total to approximately the total hired in the past.

Table 17. Landscape Services Hired in the Past and Desired in the Future (Respondents in the Northeast Region. 1959)

\begin{tabular}{l|c|c}
\hline \multicolumn{1}{c|}{ Type of Service } & $\begin{array}{c}\text { Services Hired } \\
\text { In Past }\end{array}$ & $\begin{array}{c}\text { Respondents Desiring } \\
\text { Future Services }\end{array}$ \\
\hline & Percent & Percent \\
\cline { 2 - 3 } Planting & 31 & 20 \\
Tree Surgery - & 20 & 18 \\
Specialist Caretaking & 19 & 27 \\
Handyman Caretaking (Semi-skilled) & 18 & 22 \\
Spraying and Dusting & 12 & 13 \\
Total & 100 & 100 \\
$\quad$ Number & $546^{*}$ & 366 \\
\hline
\end{tabular}

*These 546 services were hired by 365 respondents; 1,070 respondents hired no services; and 10 did not report about services hired.

As family income rose from less than $\$ 2,000$ to $\$ 10,000$ or more, the percentage of services hired also rose, until respondents in the $\$ 10$,000 -or-more income bracket hired services about twice as often as respondents in the less-than- $\$ 2,000$-income class* (Table 18). Data untabulated in this bulletin indicate that respondents whose incomes were less than $\$ 2,000$ hired semi-skilled (handyman) services more often than respondents whose incomes ranged from $\$ 2,000$ to $\$ 8,000 *$ Data in Table 19 offer an explanation for this high rate of semi-skilled employment by low-income respondents. About four-fifths of the respondents in the less-than-\$2,000-income bracket were at least 61 years old.* Possibly many were physically unable to give adequate care to their lawns and to their plantings. These respondents apparently chose to hire semi- 
Table 18. Family Income and Landscape Services Hired (Respondents in the Northeast Region. 1959)

\begin{tabular}{l|c|c|c|c}
\hline \hline $\begin{array}{c}\text { Family Income* } \\
\text { (Dollars) }\end{array}$ & $\begin{array}{c}\text { Respondents } \\
\text { Who Hired } \\
\text { Services }\end{array}$ & $\begin{array}{c}\text { Respondents } \\
\text { Who Did } \\
\text { Not Hire } \\
\text { Services }\end{array}$ & \multicolumn{2}{|c}{ Total } \\
\hline & Percent & Percent & Percent & Number \\
\cline { 2 - 5 } 2,000 & 26 & 74 & 100 & 57 \\
$2,000-3,999$ & 23 & 77 & 100 & 115 \\
$4,000-5,999$ & 12 & 88 & 100 & 391 \\
$6,000-7,999$ & 18 & 82 & 100 & 314 \\
$8,000-9,999$ & 31 & 69 & 100 & 187 \\
10,000 or More & 51 & 49 & 100 & 260 \\
Total & 25 & 75 & 100 & $1,324 * *$ \\
\hline
\end{tabular}

*Among the 365 respondents who had hired services, 34 either did not report family income or services hired.

* Among the 1,445 respondents, 112 did not report their incomes, and 9 gave no recorded responses about services hired.

\section{Table 19. Age and Family Income (Respondents in the Northeast Region. 1959)}

\begin{tabular}{c|c|c|c|c|c|c}
\hline \hline \multirow{2}{*}{$\begin{array}{c}\text { Family Income } \\
\text { (Dollars) }\end{array}$} & \multicolumn{5}{|c|}{ Respondents Age } & \multicolumn{2}{|c}{ Total } \\
\cline { 2 - 7 } & 30 or Less & $31-39$ & $40-59$ & 60 or More & \multicolumn{2}{|c}{} \\
\hline & Percent & Percent & Percent & Percent & Percent & Number \\
\cline { 2 - 7 } Under 2,000 & 2 & 2 & 14 & 82 & 100 & 57 \\
$2,000-3,999$ & 7 & 25 & 51 & 100 & 114 \\
$4,000-5,999$ & 15 & 37 & 36 & 12 & 100 & 393 \\
$6,000-7,999$ & 15 & 33 & 42 & 10 & 100 & 311 \\
$8,000-9,999$ & 11 & 32 & 50 & 7 & 100 & 185 \\
10,000 or More & 10 & 24 & 53 & 13 & 100 & 263 \\
All Classes & 12 & 30 & 41 & 17 & 100 & $1,323^{*}$ \\
\hline
\end{tabular}

*Among the 1,445 respondents, 122 either did not estimate their incomes or report their ages.

skilled services instead of allowing the grounds around their homes to deteriorate.

Slightly more semi-skilled services were planned for the future than were hired in the past: 22 and 18 percent, respectively (Table 17). Many of these future services may be hired by low-income, elderly homeowners. Retail and service nurserymen might profit by catering to this group of homeowners.

\section{Factors Related to Purchases}

\section{FAMILY INCOME}

Table 20 shows the relationship between family income and landscape expenditures in 1958. Although about 8 percent of the respondents did not divulge their family income (112 among 1,445), the Table indicates that, in general, average landscape expenditures increased as family income increased. However, the increase between the two income brackets 
Table 20. Family Income and Recent Landscape Expenditures (Respondents in the Northeast Region. July 1, 1958-June 30, 1959)

\begin{tabular}{l|c|c|c|c}
\hline \hline \multirow{2}{*}{$\begin{array}{c}\text { Family Income } \\
\text { (Dollars) }\end{array}$} & Homes & $\begin{array}{c}\text { Purchases } \\
\text { Per } 100 \\
\text { Homes }\end{array}$ & $\begin{array}{c}\text { Proportlon } \\
\text { of Total } \\
\text { Value* }\end{array}$ & $\begin{array}{c}\text { Average } \\
\text { Per Home* }\end{array}$ \\
\cline { 3 - 5 } & & Number & Percent & Dollars \\
\hline & Percent & 16 & 1 & .96 \\
$2,000-3,999$ & 4 & 14 & 2 & 2.18 \\
$4,000-5,999$ & 9 & 31 & 20 & 6.86 \\
$6,000-7,999$ & 29 & 37 & 20 & 8.65 \\
$8,000-9,999$ & 24 & 32 & 20 & 14.50 \\
10,000 or More & 14 & 42 & 37 & 18.88 \\
All Classes & 20 & 32 & 100 & 10.06 \\
Number & 100 & & & \\
\hline
\end{tabular}

* Inclusive of garden supplies. Garden supplies totaled $\$ 761$.

**Family income was not recorded by 112 respondents who made 67 purchases totaling $\$ 952$.

between $\$ 4,000$ and $\$ 8,000$ was comparatively small—only $\$ 1.80$; and the ratio of purchases to the number of homes did not increase consistently among the three income brackets between $\$ 4,000$ and $\$ 10,000$. The data indicate that homeowners with incomes ranging from $\$ 4,000$ to $\$ 8,000$ vary little in their landscape expenditures, and that about one in six owners in the lowest income bracket buys ornamentals, even though his purchases are low in dollar value.

Data not listed in table form show that present family income had little association with past patronage of chain stores for trees and shrubs, for one-half to one-third of the respondents in each income bracket had purchased ornamentals from chain stores. The ratios of recent chain store purchases to owner income also showed no steady trend (Table $21)$. The highest ratio $(7-100)$ was both in the lowest income group and

Table 21. Family Income and Purchases at Chain Stores and at Nurseries (Family income and respondents' tree and shrub expenditures at chain stores and at nurseries. Northeast Region. July 1, 1958-June 30, 1959)

\begin{tabular}{l|c|c|c}
\hline \hline $\begin{array}{c}\text { Family Income } \\
\text { (Dollars) }\end{array}$ & Homes & \multicolumn{2}{|c}{ Purchases Per 100 Homes: } \\
\cline { 3 - 4 } & $\begin{array}{c}\text { Direct From } \\
\text { Chain Stores }\end{array}$ & $\begin{array}{c}\text { Direct From } \\
\text { Nursertes }\end{array}$ \\
\hline & Percent & Number & Number \\
\hline Under 2,000 & 4 & 7 & 7 \\
$2,000-3,999$ & 9 & 2 & 9 \\
$4,000-5,999$ & 29 & 7 & 18 \\
$6,000-7,999$ & 24 & 5 & 24 \\
$8,000-9,999$ & 14 & 3 & 26 \\
10,000 or More & 20 & 5 & 30 \\
All Classes & 100 & 5 & 22 \\
Number & $1,333^{*}$ & & \\
\hline
\end{tabular}

- Income was not recorded by 112 respondents. These respondents made 19 nursery and 5 chain store purchases. 
the $\$ 4,000-\$ 5,999$ group. The lowest ratios (2-100 and 3-100) were in the next-to-lowest and next-to-highest income groups. On the other hand, as respondents' family incomes increased, their landscape expenditures at nurseries tended to increase.

The relationship between family income and landscape expenditures planned for a three-year period is shown in Table 22. Relatively more owners in the highest income bracket planned to spend at least $\$ 300$ than did owners in any other income bracket.* However, a slightly smaller proportion of owners in the highest bracket planned expenditures than did owners in any one of the three brackets which ranged from $\$ 4,000$ to $\$ 10,000$. Only minor differences in the proportion of planned expenditures existed between the two lowest income brackets, and also among the three categories between $\$ 4,000$ and $\$ 10,000$. Evidently present family income has little effect upon landscape expenditures planned for the next three years, except when income falls below $\$ 4,000$. The analysis gives some indication that middle-income owners do most of the repeat buying measured in number of purchases, but that upper-income owners spend the most per purchase.

Table 22. Family Income and Planned Expenditures (Family income and respondents' tree-and-shrub expenditures planned for the next three years. Northeast Region. 1959)

\begin{tabular}{l|c|c|c|c}
\hline \multirow{2}{*}{$\begin{array}{c}\text { Family Income } \\
\text { (Dollars) }\end{array}$} & \multirow{2}{*}{ Respondents } & \multicolumn{3}{|c}{ Proportion of Respondents Planning } \\
\cline { 3 - 5 } & & $\begin{array}{c}\text { Less Than } \\
\$ 100\end{array}$ & $\$ 100-\$ 299$ & $\begin{array}{c}\$ 300 \\
\text { or More }\end{array}$ \\
\hline & Percent & Percent & Percent & Percent \\
\hline Under 2,000 & 4 & 1 & 0 & 0 \\
$2,000-3,999$ & 9 & 3 & 0 & 0 \\
$4,000-5,999$ & 29 & 27 & 6 & 1 \\
$6,000-7,999-14$ & 24 & 21 & 7 & 1 \\
$8,000-9,999-$ & 14 & 4 & 1 \\
10,000 or More & 20 & 9 & 5 & 3 \\
Total & 100 & 72 & 22 & 6 \\
Number & $1,333^{*}$ & & & \\
\hline
\end{tabular}

\section{AGE OF HOUSE AND LENGTH OF OCCUPANCY}

In Table 23, purchases made in 1958 are classified by age of house. As house age increased, the purchases-to-homes ratio decreased. The largest difference was between relatively new houses (4 years or less) and houses 5 to 20 years old.* Only about one-sixth of the houses were within the new-house group, but the average purchase value within this 
Table 23. House Age and Recent Expenditures (House age and respondents' expenditures for trees and shrubs. Northeast Region.

July 1, 1958-June 30, 1959)

\begin{tabular}{l|c|c|c}
\hline \multicolumn{1}{c|}{$\begin{array}{c}\text { House Age } \\
\text { (Years) }\end{array}$} & Homes & $\begin{array}{c}\text { Purchases } \\
\text { Per } 100 \\
\text { Homes }\end{array}$ & $\begin{array}{c}\text { Average } \\
\text { Size of } \\
\text { Purchase }\end{array}$ \\
\hline & Percent & Number & Dollars \\
\cline { 2 - 4 } or Less & 16 & 64 & 41 \\
$5-19$ M & 34 & 32 & 21 \\
20 or More & 50 & 27 & 22 \\
All Classes & 100 & 29 & 27 \\
$\quad$ Number & $1,440^{*}$ & & \\
\hline
\end{tabular}

*The 1,440 respondents recorded in this table spent $\$ 13,603$, and house age was not reported by five respondents who made two purchases amounting to $\$ 3$.

group was about twice as great as in any other group. Evidently the expansion of the ornamentals nursery business is closely associated with the construction of houses for owner occupants.

Table 24 relates purchases made in 1958 to the number of years owners had occupied their homes. During the second, third, fourth, and fifth years, the purchases-to-homes ratios were higher than during the first year, but after the fifth year the ratios declined slightly from class to class. The largest average purchases were during the first and second years of tenure;* thereafter averages were irregular, with slightly the largest occurring among purchasers who had occupied their home more than 20 years.

Table 24. Years in Residence and Recent Expenditures (Respondents' years in residence and expenditures for trees and shrubs.

Northeast Region. July 1, 1958-June 30, 1959)

\begin{tabular}{l|c|c|c}
\hline \hline Years in Residence & $\begin{array}{c}\text { Number of } \\
\text { Homes }\end{array}$ & $\begin{array}{c}\text { Purchases } \\
\text { Per 100 } \\
\text { Homes }\end{array}$ & $\begin{array}{c}\text { Average } \\
\text { Purchase } \\
\text { Value }\end{array}$ \\
\hline & Percent & Number & Dollars \\
\hline & 12 & 34 & 47 \\
3 & 7 & 52 & 40 \\
$4-$ & 8 & 43 & 26 \\
$5-10-$ & 7 & 49 & 25 \\
$11-20$ & 6 & 51 & 15 \\
21 or More & 22 & 31 & 24 \\
All Classes & 21 & 27 & 17 \\
Number & 17 & 25 & 28 \\
\end{tabular}

*The 1,442 respondents recorded in this table spent $\$ 13,579$. The number of years in residence was not reported by three respondents who made two purchases which totaled $\$ 27$. In this table 497 purchases are involved.

*Significant. 
At first glance the data shown in Table 25 seem to contradict the data in Table 24. Table 25 indicates that about half of all major plantings were made during the first year of occupancy; but Table 24 indicates that in 1958 proportionately more purchases were made by respondents in their second year of tenure than in their first.* However, Table 24 also shows that in 1958 the average value of first-year occupants' purchases was greater than the average value of second-year purchases. Apparently respondents classed these larger, first-year purchases as major plantings.

Table 26 shows the relationship of house age at occupancy to 1958 purchases. No trend is noticeable in the number of purchases per 100 homes. The highest ratio of purchases to homes was among respondents who had moved into houses one year old or less, but the difference between the first- and second-year ratios was not significant.

Table 25. Years in Residence and Major Plantings (Home-owners' years in residence when major plantings of trees and shrubs were made. Respondents in the Northeast Region. 1959)

\begin{tabular}{|c|c|}
\hline Years in Residence & Major Plantings \\
\hline & Percent \\
\hline 1 or Less & 48 \\
\hline $2 \ldots$ & 15 \\
\hline $3 \ldots$ & 8 \\
\hline$-1-1-1-1-1-1-1-1-1-1$ & 5 \\
\hline 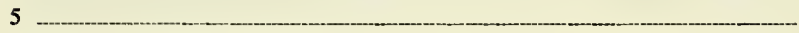 & 6 \\
\hline $6-10 \ldots \ldots$ & 9 \\
\hline 11 or More & 9 \\
\hline Total & 100 \\
\hline Number & $1,096^{*}$ \\
\hline
\end{tabular}

*Several respondents made more than one major planting. The 1,096 major plantings were made by 828 respondents, and only minor plantings were made by 365 respondents.

Table 26. Age of House at Occupancy and Recent Expenditures (Age of house at occupancy and respondents' expenditures for trees and shrubs. Northeast Region. 1959)

\begin{tabular}{l|c|c|c}
\hline $\begin{array}{c}\text { Age of House at Occupancy } \\
\text { YYears) }\end{array}$ & Homes & $\begin{array}{c}\text { Purchases } \\
\text { Per 100 } \\
\text { Homes }\end{array}$ & $\begin{array}{c}\text { Average } \\
\text { Size } \\
\text { Purchase }\end{array}$ \\
\hline & Percent & Number & Dollars \\
\cline { 2 - 4 } or Less & 42 & 39 & 35 \\
$2-5$ & 9 & 28 & 38 \\
$6-10$ & 9 & 32 & 22 \\
$11-20$ & 12 & 30 & 22 \\
21 or More & 28 & 22 & 19 \\
All Classes & 100 & 32 & 30 \\
Number & $1,444^{*}$ & & \\
\hline
\end{tabular}

*One respondent did not report how old his house had been when he first occupied it. Total expenditures were $\$ 13,606$.

*Significant. 
Owners occupying houses less than five years old planned proportionately more tree-and-shrub purchases in all expenditure classes than did other owners* (Table 27). Evidently new developments offer excellent opportunities for nurserymen to expand their businesses, but the best opportunity exists before houses are five years old.

Table 27. Age of House and Planned Expenditures (Age of house and respondents' tree-and-shrub expenditures planned for the next three years. Northeast Region. 1959)

\begin{tabular}{|c|c|c|c|c|}
\hline \multirow{2}{*}{$\begin{array}{c}\text { Planned Expenditures } \\
\text { (Dollars) }\end{array}$} & \multicolumn{3}{|c|}{ Age of House (Years) } & \multirow{2}{*}{$\begin{array}{l}\text { Total } \\
\text { Houses }\end{array}$} \\
\hline & 4 or Less & $5-19$ & 20 or More & \\
\hline & Percent & Percent & Percent & Percent \\
\hline Less than 50 & 16 & 15 & 14 & 14 \\
\hline $50-99-1$ & 15 & 8 & 8 & 9 \\
\hline $100-199 \quad \ldots \quad \ldots$ & 15 & 4 & 3 & 5 \\
\hline $200-299$ & 4 & 1 & 1 & 2 \\
\hline $300-499 \ldots$ & 2 & 1 & 1 & 1 \\
\hline 500 or More & 4 & $0 *$ & $0 *$ & 1 \\
\hline No Specific Amount & 11 & 9 & 5 & 8 \\
\hline None or Undecided & 33 & 62 & 68 & 60 \\
\hline Total & 100 & 100 & 100 & 100 \\
\hline Number & 228 & 487 & 725 & 1,440 ** \\
\hline
\end{tabular}

*Less than $1 / 2$ of 1 percent.

*House age was not reported by five respondents.

\section{DRAWN LANDSCAPE PLANS}

About one in five owners of homes less than 20 years old possessed drawn landscape plans, * but owners of houses less than five years old did not have proportionately more plans than owners of houses 5 to 20 years old (Table 28). Table 29 shows that as family income increased, the possession of drawn landscape plans increased; Table 30 shows that as the possession of drawn plans increased, since-occupancy expenditures

Table 28. Age of House and Drawn Landscape Plan (Respondents in the Northeast Region. 1959)

\begin{tabular}{l|c|c|c|c}
\hline \multirow{2}{*}{$\begin{array}{c}\text { House Age } \\
\text { (Years) }\end{array}$} & \multicolumn{2}{|c|}{ Respondents } & \multicolumn{2}{c}{ Total } \\
\cline { 2 - 5 } & $\begin{array}{c}\text { Whth } \\
\text { Drawn } \\
\text { Plans }\end{array}$ & $\begin{array}{c}\text { With No } \\
\text { Drawn } \\
\text { Plans }\end{array}$ & \multicolumn{2}{|c}{ Number } \\
\hline & Percent & Percent & Percent & 228 \\
4 or Less & 21 & 79 & 100 & 487 \\
$5-19$ & 23 & 77 & 100 & 725 \\
20 or More & 9 & 91 & 100 & $1,440^{*}$ \\
All Classes & 16 & 84 & 100 &
\end{tabular}

*Five respondents did not report the age of their houses, and two of these five had drawn plans.

* Significant. 
Table 29. Family Income and Drawn Landscape Plan (Respondents in the Northeast Region. 1959)

\begin{tabular}{l|c|c|c|c}
\hline \hline \multirow{2}{*}{$\begin{array}{c}\text { Income } \\
\text { (Dollars) }\end{array}$} & \multicolumn{2}{|c|}{ Respondents } & \multicolumn{2}{c}{ Total } \\
\cline { 2 - 5 } & $\begin{array}{c}\text { With } \\
\text { Drawn } \\
\text { Plans }\end{array}$ & $\begin{array}{c}\text { With No } \\
\text { Drawn } \\
\text { Plans }\end{array}$ & \multicolumn{2}{|c}{ Number } \\
\hline & Percent & Percent & Percent & 55 \\
Less than 2,000 & 4 & 96 & 100 & 113 \\
$2,000-3,999$ & 9 & 91 & 100 & 686 \\
$4,000-7,999$ & 14 & 86 & 100 & 181 \\
$8,000-9,999$ & 22 & 78 & 100 & 248 \\
10,000 or More & 27 & 73 & 100 & $1,283^{*}$ \\
All Classes & 17 & 83 & 100 & \\
\hline
\end{tabular}

*Among the 1,445 respondents, 112 did not report their family incomes, and 50 of those who did report incomes gave no responses about possession of drawn landscape plans.

Table 30. Drawn Landscape Plans and Past Expenditures (Drawn Iandscape plans and respondents' expenditures for trees and shrubs since occupying their homes. Northeast Region. 1959)

\begin{tabular}{l|c|c|c|c}
\hline \multirow{2}{*}{$\begin{array}{c}\text { Since-Occupancy Expenditures } \\
\text { (Dollars) }\end{array}$} & \multicolumn{2}{|c|}{ Respondents } & \multicolumn{2}{|c}{ Total } \\
\cline { 2 - 5 } & $\begin{array}{c}\text { With } \\
\text { Drawn } \\
\text { Plans }\end{array}$ & $\begin{array}{c}\text { With No } \\
\text { Drawn } \\
\text { Plans }\end{array}$ & \multicolumn{2}{|c}{} \\
\hline \multirow{3}{*}{ Less than 25} & Percent & Percent & Percent & Number \\
$25-49$ & 5 & 95 & 100 & 317 \\
$50-99$ & 9 & 91 & 100 & 154 \\
$100-199$ & 16 & 84 & 100 & 230 \\
$200-299$ & 27 & 73 & 100 & 205 \\
$300-499$ & 37 & 63 & 100 & 117 \\
$500-999$ & 33 & 67 & 100 & 79 \\
1,000 or More & 35 & 65 & 100 & 49 \\
All Classes & 47 & 53 & 100 & 32 \\
\hline
\end{tabular}

*Among the 1,193 respondents who reported past purchases, 10 gave no responses about drawn plans.

tended to increase; and Table 31 shows that owners with drawn plans made greater tree-and-shrub expenditures in 1958 than owners with no drawn plans.* About two-thirds of the respondents who had drawn plans had procured them during the first year of home occupancy* (Table 32). Evidently the possession of drawn plans is an excellent indicator of both past and current expenditures for trees and shrubs. Because most plans apparently are procured immediately after occupancy, nurserymen might expand their businesses by inducing both owners in new developments and newcomers to older developments to procure landscape sketches.

Table 33 indicates that only slight differences existed between landscape expenditures made by owners who had commercially-drawn plans and owners who had non-commercially-drawn plans.

*Significant. 
Table 31. Drawn Landscape Plans and Recent Expenditures (Drawn landscape plans and respondents' expenditures for trees and shrubs. Northeast Region. July 1, 1958-June 30, 1959)

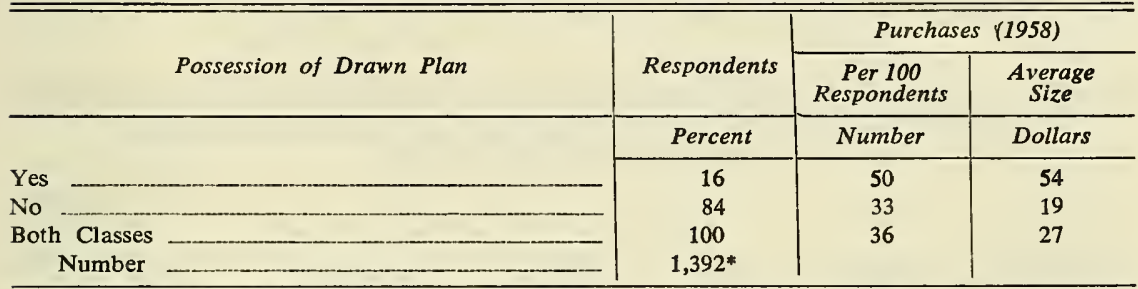

*Among the 1,445 respondents, 53 did not report about the possession of a drawn landscape plan. Three purchases, amounting to $\$ 163$, were made by respondents who did not report about the possession of a drawn landscape plan. In this table 496 purchases are recorded.

Table 32. When Drawn Plans Were Obtained (Years in residence when respondents obtained drawn landscape plans. Northeast Region. 1959)

\begin{tabular}{l|c}
\hline \hline $\begin{array}{c}\text { Length of Residence When Plan Was Obtained } \\
(\text { Years })\end{array}$ & $\begin{array}{c}\text { Respondents } \\
\text { With Plans }\end{array}$ \\
\hline & Percent \\
1 or Less & 65 \\
$2-5$ & 23 \\
$6-10$ & 7 \\
$11-20$ & 2 \\
21 or More & 3 \\
Total Number & 100 \\
$\quad$ & $187^{*}$ \\
\hline
\end{tabular}

*Among the owners who reported 228 drawn plans, 41 did not report how long they had been in residence when they obtained the plans.

Table 33. Source of Drawn Plans and Past Expenditures (Source of drawn plan and respondents' expenditures for trees and shrubs since occupying their homes. Northeast Region. 1959)

\begin{tabular}{|c|c|c|c|c|c|c|c|c|}
\hline \multirow{2}{*}{$\begin{array}{c}\text { Source } \\
\text { of } \\
\text { Plan }\end{array}$} & \multicolumn{8}{|c|}{ Since-Occupancy Expenditures of Respondents with Plans: } \\
\hline & $\begin{array}{c}\text { Less } \\
\text { Than } \\
\$ 50\end{array}$ & $\underset{\$ 50-}{\$ 50-}$ & $\$ 100-$ & $\$ 200-$ & $\begin{array}{l}\$ 300- \\
\$ 999\end{array}$ & $\begin{array}{c}\$ 1,000 \\
\text { or } \\
\text { More }\end{array}$ & \multicolumn{2}{|c|}{ Total } \\
\hline & Percent & Percent & Percent & Percent & Percent & Percent & Percent & Number* \\
\hline Commercial & 11 & 18 & 25 & 20 & 20 & 6 & 100 & 142 \\
\hline Non-Commercial & 17 & 11 & 27 & 13 & 22 & 10 & 100 & 63 \\
\hline
\end{tabular}

*Among the 228 respondents who had drawn plans, 23 either did not report the source of their plans or their since-occupancy expenditures for trees and shrubs.

\section{EDUCATION}

Proportionately about twice as many respondents who had attended college had spent $\$ 300$ or more for trees and shrubs since occupying their homes as had respondents whose formal education had ended in elementary 
or in high school* (Table 34). However, there were only slight differences in expenditures between respondents whose education had ended in elementary school and in high school. Respondents who had attended college also averaged the largest expenditures in 1958* (Table 35).

Table 34. Education and Past Expenditures (Education and respondents' expenditures for trees and shrubs since occupying their homes. Northeast Region. 1959)

\begin{tabular}{l|c|c|c|c|c|c}
\hline \hline $\begin{array}{c}\text { Highest Level } \\
\text { of Education }\end{array}$ & \multicolumn{6}{|c}{ Respondents Whose Expenses Were: } \\
\cline { 2 - 7 } & $\begin{array}{c}\text { Less Than } \\
\$ 100\end{array}$ & $\begin{array}{c}\$ 100- \\
\$ 299\end{array}$ & $\begin{array}{c}\$ 300 \text { or } \\
\text { More }\end{array}$ & $\begin{array}{c}\text { Not Re- } \\
\text { ported }\end{array}$ & \multicolumn{2}{|c}{ Total } \\
\hline & Percent & Percent & Percent & Percent & Percent & Number \\
\cline { 2 - 7 } & & 26 & 7 & 16 & 100 & 179 \\
Elementary & 51 & 22 & 8 & 18 & 100 & 781 \\
School School_ & 52 & 21 & 18 & 19 & 100 & 463 \\
College - & 42 & & & & 100 & $1,423^{*}$ \\
All Classes & & &
\end{tabular}

*Among the 1,445 respondents, 22 did not report their highest level of education.

Table 35. Education and Recent Expenditures (Education and respondents' expenditures for trees and shrubs. Northeast

Region. July 1, 1958-June 30, 1959)

\begin{tabular}{l|c|c|c|c|c}
\hline \multirow{2}{*}{$\begin{array}{c}\text { Highest Level } \\
\text { of Education }\end{array}$} & Respondents & $\begin{array}{c}\text { Per 100 } \\
\text { Respondents }\end{array}$ & $\begin{array}{c}\text { Per } \\
\text { Respondent }\end{array}$ & $\begin{array}{c}\text { Average } \\
\text { Size }\end{array}$ & Number \\
\hline & Percent & Number & Dollars & Dollar & Percent \\
\cline { 2 - 6 } Elementary School & 13 & 17 & 2.21 & 12.74 & 7 \\
High School & 55 & 33 & 8.70 & 26.34 & 56 \\
College & 32 & 37 & 13.85 & 37.95 & 37 \\
All Cases & 100 & 32 & 9.56 & 29.71 & 100 \\
Number & $1,423^{*}$ & & & & \\
\hline
\end{tabular}

*Among the 1,445 respondents, 22 did not report their educational attainment, and among the 499 purchases, specific amounts spent for plants were not reported in 41 cases.

The data indicate that high school and elementary school graduates spend about the same amounts for trees and shrubs, but that college graduates spend appreciably more. However, family income rather than level of education may be the causal force involved.

\section{PROPERTY VALUE}

Table 36 shows that in 1958 per-respondent expenditures rose from property-value class to property-value class until owners in the top class spent about 12 times as much per owner as owners in the lowest class.* However, the differences between per-respondent expenditures were slight between the two lowest property-value classes and between the two middle- 
Table 36. Property Value and Recent Expenditures (Property value and respondents ${ }^{9}$ expenditures for trees and shrubs, Northeast Region. July 1, 1958-June 30, 1959)

\begin{tabular}{l|c|c|c}
\hline \multirow{2}{*}{$\begin{array}{c}\text { Property Value } \\
\text { (Dollars) }\end{array}$} & Respondents & \multicolumn{2}{|c}{ Purchases } \\
\cline { 3 - 4 } & $\begin{array}{c}\text { Per 100 } \\
\text { Respondents }\end{array}$ & $\begin{array}{c}\text { Per } \\
\text { Respondent }\end{array}$ \\
\hline Less than 10,000 & Percent & Number & Dollars \\
$10,000-14,999$ & 3 & 15 & 3.15 \\
$15,000-19,999$ & 34 & 22 & 3.47 \\
$20,000-29,999$ & 33 & 41 & 9.24 \\
30,000 or More & 21 & 33 & 11.29 \\
All Cases & 9 & 37 & 36.31 \\
Number & 100 & 32 & 9.95 \\
\hline
\end{tabular}

*Among the 1,445 respondents, 16 did not report the value of their property. In this table 456 purchases were involved.

value classes. Owners of residences valued at $\$ 30,000$ or more averaged expenditures at about three times as great as owners in any other class.*

Respondents whose homes were valued at $\$ 30,000$ or more had spent at least $\$ 1,000$ for trees and shrubs relatively the most often* and had spent less than $\$ 100$ relatively the least often* (Table 37 ). Table 38 shows that the highest property-value homeowners planned to make proportionately the most $\$ 500$-or-more purchases and proportionately the least less-than- $\$ 100$ purchases. ${ }^{*}$ However, only about 24 percent of the group planned to make future purchases, relatively a few less than either of the other groups. The data indicate that the extremes of property value are reliable indicators of past, present, and future expenditures for trees and shrubs.

Table 37. Property Value and Past Expenditures (Property value and respondents' expenditures for trees and shrubs since occupying their homes. Northeast Region. 1959)

\begin{tabular}{l|c|c|c|c}
\hline \hline \multirow{2}{*}{$\begin{array}{c}\text { Expenditures } \\
\text { (Dollars) }\end{array}$} & \multicolumn{2}{|c|}{ Respondents } & With Residences Valued At: & \multirow{2}{*}{ Total } \\
\cline { 2 - 4 } & $\begin{array}{c}\text { Less Than } \\
\$ 20,000\end{array}$ & $\begin{array}{c}\$ 20,000- \\
\$ 29,999\end{array}$ & $\begin{array}{c}\$ 30,000 \text { or } \\
\text { More }\end{array}$ & \\
\hline & Percent & Percent & Percent & Percent \\
\cline { 2 - 4 } Less than 100 & 54 & 31 & 20 & 46 \\
$100-499$ & 22 & 41 & 38 & 27 \\
$500-999$ & 1 & 7 & 10 & 4 \\
1,000 or More & $0 *$ & 2 & 16 & 2 \\
None or Not Reported & 23 & 19 & 16 & 21 \\
Total & 100 & 100 & 100 & 100 \\
Number & 1,008 & 293 & 128 & $1,429^{* *}$ \\
\hline
\end{tabular}

*Less than $1 / 2$ of 1 percent.

* The value of residences was not reported by 16 respondents.

*Significant. 
Table 38. Property Value and Planned Expenditures (Respondents' property value and expenditures planned for trees and shrubs during the next three year period. Northeast Region. 1959)

\begin{tabular}{l|c|c|c|c}
\hline \hline \multirow{2}{*}{$\begin{array}{c}\text { Expenditures Planned } \\
\text { (Dollars) }\end{array}$} & \multicolumn{2}{|c|}{ Respondents } & With Residences Valued At: & \multirow{2}{*}{ Total } \\
\cline { 2 - 4 } & $\begin{array}{c}\text { Less Than } \\
\$ 20,000\end{array}$ & $\begin{array}{c}\$ 20,000- \\
\$ 29,999\end{array}$ & $\begin{array}{c}\$ 30,000 \\
\text { or More }\end{array}$ & \\
\hline & Percent & Percent & Percent & Percent \\
\cline { 2 - 4 } Less than 100 & 25 & 22 & 5 & 23 \\
$100-199-$ & 4 & 8 & 7 & 5 \\
$200-299$ & 1 & 3 & 4 & 2 \\
$300-499-$ & 1 & 1 & 3 & 1 \\
$500-$ or More & $0 *$ & 1 & 5 & 1 \\
None or Not Reported & 69 & 65 & 76 & 68 \\
Total & 100 & 100 & 100 & 100 \\
Number & 1,008 & 293 & 128 & $1,429 * *$ \\
\hline
\end{tabular}

*Less than $1 / 2$ of 1 percent.

* Among the 1,445 respondents, 16 did not estimate the value of their property.

\section{SIZE OF LANDSCAPE AREA}

There were slight differences in since-occupancy tree-and-shrub expenditures among respondents in various landscape area classes, but only one difference was statistically significant (Table 39). Proportionately twice as many owners spent $\$ 300$ or more if their homes had landscape areas of at least 40,000 square feet than if their landscape areas ranged from 200 to 5,000 square feet. The data indicate only that owners of homes with lawns about an acre or more in size spend more for trees and shrubs than owners of homes with lawns not larger than about one-tenth of an acre.

Table 39. Size of Landscape Area and Past Expenditures (Size of landscape area and respondents' expenditures for trees and shrubs since occupying their homes. Northeast Region. 1959)

\begin{tabular}{l|c|c|c|c|c|c}
\hline \hline $\begin{array}{c}\text { Size of } \\
\text { Landscape } \\
\begin{array}{c}\text { Area } \\
\text { (Sq. Feet) }\end{array}\end{array}$ & $\begin{array}{c}\text { Less Than } \\
\$ 100\end{array}$ & $\begin{array}{c}\$ 100- \\
\$ 299\end{array}$ & $\begin{array}{c}\$ 300 \text { or } \\
\text { More }\end{array}$ & None & \multicolumn{2}{|c}{ Total Respondents } \\
\hline & Percent & Percent & Percent & Percent & Percent & Number* \\
\hline $200-4,999$ & 54 & 21 & 9 & 16 & 100 & 710 \\
$5,000-9,999-$ & 42 & 23 & 13 & 22 & 100 & 369 \\
$10,000-$ & 46 & 25 & 12 & 17 & 100 & 290 \\
$39,999-$ & 46 & 13 & 18 & 23 & 100 & 70 \\
40,000 or & 46 & &
\end{tabular}

*The size of the landscape areas around 6 of the 1,445 homes was not recorded.

\section{URBANIZATION OF RESIDENCES}

Tables 40,41 , and 42 show the relationships between urbanization of residences and past, recent, and planned expenditures for trees and shrubs. The differences between rural nonfarm and urban past expendi- 
Table 40. Urbanization of Residences and Past Expenditures (Urbanization of residences and respondents' expenditures for trees and shrubs since occupying their homes. Northeast Region. 1959)

\begin{tabular}{l|c|c|c|c|c|c}
\hline \hline \multirow{2}{*}{$\begin{array}{c}\text { Urbaniza- } \\
\text { tion of } \\
\text { Residence }\end{array}$} & $\begin{array}{c}\text { Less Than } \\
\$ 100\end{array}$ & $\begin{array}{c}\$ 100- \\
\$ 199\end{array}$ & $\begin{array}{c}\$ 200 \text { or } \\
\text { More }\end{array}$ & None & \multicolumn{2}{|c}{ Total Respondents } \\
\hline & Percent & Percent & Percent & Percent & Percent & Number \\
\cline { 2 - 7 } & 49 & 13 & 16 & 22 & 100 & 549 \\
Urban & 44 & 15 & 22 & 19 & 100 & 730 \\
Suburban - & 46 & 14 & 16 & 24 & 100 & 158 \\
Rural Non- & 46 & 19 & 21 & 100 & $1,437^{*}$ \\
Farm & 46 & 14 & 19 &
\end{tabular}

*Among the 1,445 residences, 8 were not classified by degree of urbanization.

Table 41. Urbanization of Residence and Recent Expenditures for Trees and Shrubs (Respondents in the Northeast Region. July 1, 1958-June 30,1959 )

\begin{tabular}{|c|c|c}
\hline \multirow{3}{*}{ Respondents } & \multicolumn{2}{|c}{ Purchases } \\
\cline { 2 - 3 } & $\begin{array}{c}\text { Per 100 } \\
\text { Respondents }\end{array}$ & $\begin{array}{c}\text { Per } \\
\text { Respondent }\end{array}$ \\
\hline Percent & Number & Dollars \\
\hline 38 & 29 & 6.89 \\
51 & 40 & 11.84 \\
11 & 26 & 6.35 \\
100 & 34 & 9.35 \\
$1,437^{*}$ & & \\
\hline
\end{tabular}

Urban

Suburban

Rural Non-Farm

All Classes

Number

1,437

*Eight respondents' homes were not classified by degree of urbanization. These respondents made seven purchases which totaled $\$ 175$.

Table 42. Urbanization of Residence and Planned Expenditures (Urbanization of residences and respondents' tree and shrub expenditures planned for the next three years.

Northeast Region. 1959)

\begin{tabular}{l|c|c|c|c}
\hline \hline \multirow{2}{*}{$\begin{array}{c}\text { Expenditures Planned } \\
\text { (Dollars) }\end{array}$} & \multicolumn{4}{|c}{ Homes } \\
\cline { 2 - 5 } & Urban & Suburban & $\begin{array}{c}\text { Rural } \\
\text { Non-Farm }\end{array}$ & Total \\
\hline & Percent & Percent & Percent & Percent \\
\cline { 3 - 5 } Less than 100 & 22 & 23 & 24 & 23 \\
$100-199$ & 3 & 7 & 7 & 5 \\
200 or More & 3 & 4 & 1 & 4 \\
No Definite Amount & 6 & 9 & 13 & 8 \\
None & 66 & 57 & 55 & 60 \\
Total & 100 & 100 & 100 & 100 \\
Number & 549 & 730 & 158 & $1,437^{*}$ \\
\hline
\end{tabular}

*The homes of eight respondents were not classified by degree of urbanization.

tures were slight (Table 40). Table 40 also shows that past spending by suburban owners was higher than in either of the other two urbaniza- 
tion classes.* During 1958 suburban owners also registered the highest purchases-to-homes ratio and spent the most per-person* (Table 41). Suburban owners planned to spend at least $\$ 200$ more often than either of the other two classes* (Table 42).

The data indicate that suburban residents buy the most ornamentals, but that rural nonfarm owners make as frequent and as large purchases of trees and shrubs as urban owners. Data untabulated in this bulletin show that three-tenths of the rural nonfarm purchases are by mail, but only one-eighth of the urban and suburban purchases are by mail.* Rural areas apparently offer an excellent opportunity for the expansion of the non-mail-order retail nursery trade.

\section{REMODELING}

Among the respondents who had altered their landscaping because of remodeling, about one-seventh had spent $\$ 500$ or more for trees and shrubs since occupying their homes-proportionately about three times as many as respondents who had not remodeled* (Table 43). However, landscape changes caused by remodeling were associated with only slight differences in the proportions of owners who had spent less than $\$ 500$. Apparently only remodeling which involves the alteration of extensive landscape plantings causes larger tree-and-shrub expenditures than normally would occur. The data also indicate that owners who do not remodel purchase relatively few trees and shrubs. Perhaps they tend to be satisfied with what they have, both house and grounds.

\section{Consumer Wants, Preferences, and Attitudes}

\section{PLANT PREFERENCES}

Table 44 shows the number of respondents who named specific plants when they were asked to indicate their favorite for each of three uses: foundation planting, yard planting, and border planting. About two-thirds chose a specific plant as a favorite for foundation planting, and about three-fourths of these favorites were yews, junipers, arbor-vitae, and rhododendron-all evergreens. It was not determined whether the azaleas preferred were evergreen or deciduous types. Yews were selected about three times as often as any other plant.* Homeowners apparently have a decided preference for evergreens, and among the evergreens, yews are the most popular. This positive demand for evergreen shrubs in general and for yews in particular indicates that nurserymen might find acceptance to an informative program showing the advantages of evergreen shrubs, particularly yews, over deciduous shrubs.

\footnotetext{
*Significant.
} 
Table 43. Remodeling and Past Expenditures (Remodeling of homes distributed by expenses for trees and shrubs since respondents had occupied their present homes. Northeast Region. 1959)

\begin{tabular}{|c|c|c|c|}
\hline \multirow{2}{*}{$\begin{array}{c}\text { Since-Occupancy Expenditures } \\
\text { (Dollars) }\end{array}$} & \multicolumn{2}{|c|}{$\begin{array}{c}\text { Respondents Who Had } \\
\text { Remodeled }\end{array}$} & \multirow{2}{*}{$\begin{array}{l}\text { Respondents } \\
\text { Who Had } \\
\text { Not Re- } \\
\text { modeled }\end{array}$} \\
\hline & $\begin{array}{c}\text { No } \\
\text { Landscape } \\
\text { Change }\end{array}$ & $\begin{array}{l}\text { Landscape } \\
\text { Change }\end{array}$ & \\
\hline \multirow{3}{*}{$\begin{array}{l}\text { Less than } 50 \\
50-199\end{array}$} & Percent & Percent & Percent \\
\hline & 29 & 26 & 34 \\
\hline & 38 & 37 & 29 \\
\hline $200-499$ & 19 & 16 & 12 \\
\hline-1 & 4 & 14 & 5 \\
\hline 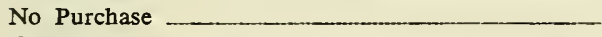 & 10 & 7 & 20 \\
\hline 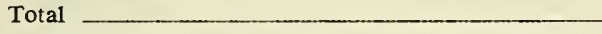 & 100 & 100 & 100 \\
\hline-1 & $117 *$ & $133 *$ & $1,192^{*}$ \\
\hline
\end{tabular}

*Among the 1,445 respondents, 3 gave no response about remodeling.

Table 44. Plant Preferences (Specific plants preferred for various uses by respondents in the Northeast Region. 1959)

\begin{tabular}{|c|c|c|c|c|c|}
\hline \multicolumn{2}{|c|}{ For Foundation } & \multicolumn{2}{|c|}{ For Yard } & \multicolumn{2}{|c|}{ For Border } \\
\hline Plant & Frequency & Plant & Frequency & Plant & Frequency \\
\hline \multirow[b]{2}{*}{ Yew …_. } & Percent & & Percent & \multirow{10}{*}{$\begin{array}{l}\text { Privet } \\
\text { Roses } \\
\text { Flowers } \\
\text { Barberry } \\
\text { Hemlock } \\
\text { Other } \\
\text { None }\end{array}$} & Percent \\
\hline & 26 & Maple & 16 & & 7 \\
\hline Azalea ___ & 9 & Spruce & 8 & & 7 \\
\hline Juniper & 8 & Roses & 7 & & 3 \\
\hline Arbor-vitate & 6 & Fruit Trees & 6 & & 2 \\
\hline Rhododendron .... & 4 & Dogwood & 6 & & 2 \\
\hline Other & 14 & Other & 26 & & 18 \\
\hline None & 33 & None ___ & 31 & & 61 \\
\hline Total & 100 & & 100 & & 100 \\
\hline Number & 1,445 & & 1,445 & & 1,445 \\
\hline
\end{tabular}

Maples were selected as favorites for use in yard plantings to about twice as frequently as any other specific plant. However, in 1958, respondents purchased to about half as many deciduous shade trees as evergreen trees* (Table 1 ). The proportion of maples among the deciduous shade trees was not determined. Although many of the evergreen trees purchased may have been misused as foundation plants, homeowners apparently did not purchase, for lawn use, the trees which they believe are most satisfactory.

Among the five most popular border plants, only three were suitable for hedge plantings, and the non-hedge plants, roses and flowers, received about one-quarter of the preference votes. However, only about 40 per- 
cent of the respondents expressed specific preferences for border plants, a much smaller proportion than the approximate two-thirds who expressed preferences for foundation or yard plants.* Apparently respondents are somewhat uninterested in hedges. The replacement of hedges with suitably chosen and suitably placed evergreen shrubs or shade trees might offer opportunities for sales expansion.

Each respondent was asked to name the most unsatisfactory plant he had used in landscaping (Table 45). About half of the respondents named specific plants in their responses. Fruit trees, junipers, arbor-vitae, barberry, pine, and maple (in order of recurrence) were rated the most unsatisfactory. The dissatisfaction with fruit trees and pines may have been caused because they were misused as foundation plants or as closelyspaced lawn trees, but the dissatisfaction with maples, junipers, and arborvitae seems to conflict with their relatively high rankings as favorites (Table 44). However, the request for plants preferred did not limit answers to actual experience, but such a limit was placed upon answers for the most unsatisfactory plant. Possibly respondents without experience tended to prefer junipers and arbor-vitae because these plants are well known and comparatively inexpensive. Preference judgments for maples may have been based upon observance of mature, well-spaced specimens; but unsatisfactory judgments for maples may have been based on the slow growth habits of specimens which had been purchased.

About one-third of the respondents were either too indifferent to ornamental plants or too ill-informed about them to select any one favorite

\section{Table 45. The Most Unsatisfactory Landscape Plants} (Respondents in the Northeast Region. 1959)

\begin{tabular}{|c|c|}
\hline Plants Selected & Respondents \\
\hline & Percent \\
\hline Fruit Trees & 11 \\
\hline Junipers & 8 \\
\hline Arbor-vitae & 7 \\
\hline Barberry & 7 \\
\hline Pine & 6 \\
\hline Maple ___ _ _ & 6 \\
\hline 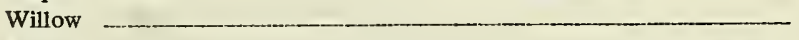 & 4 \\
\hline Roses ㄷ﹎ _ _ _ _ _ _ _ _ _ & 3 \\
\hline 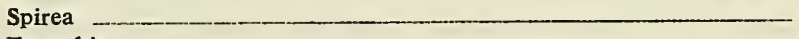 & 3 \\
\hline Forsythia & 3 \\
\hline 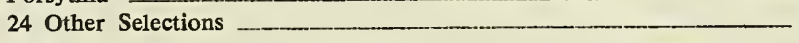 & 42 \\
\hline 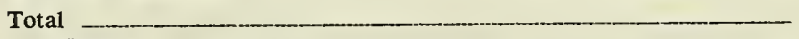 & 100 \\
\hline Number & 724* \\
\hline
\end{tabular}

*There were 25 plant choices of a general nature, and 696 respondents among the 1,445 made no specific selections.

*Significant. 
for foundation planting (Table 44). The United States Censuses of 1950 and 1955 show that, during the five-year period involved, the value of nursery-crop sales increased about three times as fast as the value of farm products in general ( 38 and 12 percents, respectively). These data indicate that homeowners are not indifferent to landscape plants. Despite their growing interest, however, owners apparently tend to be ignorant of specific kinds and species of plants. By familiarizing homeowners with the most common and most desirable ornamentals, nurserymen might encourage both the replacement of inferior plants and the planting of new areas.

\section{ATTITUDES TOWARD FURTHER PLANTINGS}

As indicated in Table 10, about 60 percent of the respondents had no definite intention to make future landscape plantings. Table 46 lists the reasons given for not planning further plantings. Among the specific reasons listed, Landscaping Complete and Unsatisfactory Past Experience occurred the most and least often, respectively.* About one-sixth of the husbands and about one-tenth of the wives listed lack of physical strength as the chief reason* (Table 47). This apparent enigma can be explained by the fact that about 30 percent of the husbands and only about 14 percent of the wives were more than 60 years old* (Table 48). The elderly husbands might tend to report that they lacked the strength to care for more landscaping; and the younger wives might tend to give other reasons.

\section{Table 46. Reasons for Planning No Future Landscape Plantings (Respondents in the Northeast Region. 1959)}

\begin{tabular}{l|c}
\hline \hline \multicolumn{1}{c|}{ Reasons } & $\begin{array}{c}\text { Respondents Giving } \\
\text { A Reason }\end{array}$ \\
\hline & Percent \\
Landscaping Complete & 53 \\
Owner Moving - & 15 \\
Insufficient Strength & 11 \\
Insufficient Money & 9 \\
Insufficient Time - & 6 \\
Unsatisfactory Past Experience & 2 \\
Other Reasons - & 4 \\
Total Number & 100 \\
Numbr & $749^{*}$ \\
\hline
\end{tabular}

*There were 96 respondents who were undecided about future plantings and 775 who definitely planned to make no more plantings. Among the latter group, 26 respondents did not report their reasons.

*Significant. 
Table 47. Lack of Physical Strength Among Husbands and Wives as a Reason for Not Making Future Landscape Plantings

(Respondents in the Northeast Region. 1959)

\begin{tabular}{l|c|c}
\hline \hline Reason for Making No Plantings & Husbands & Wives \\
\hline & Percent & Percent \\
\cline { 2 - 3 } Lack of Physical Strength & 17 & 9 \\
Other Reasons & 83 & 91 \\
Total & 100 & 100 \\
Number & $152^{*}$ & $515^{*}$ \\
\hline
\end{tabular}

*No reason was stated by 4 husbands and 14 wives.

Table 48. Family Members Interviewed, Distributed by Age (Respondents in the Northeast Region. 1959)

\begin{tabular}{l|c|c|c|c}
\hline \hline \multicolumn{1}{c|}{ Age (Years) } & Husband & Wife & Couple & Other \\
\hline & Percent & Percent & Percent & Percent \\
\cline { 2 - 5 } 30 or Less & 4 & 11 & 9 & 49 \\
$31-40$ & 23 & 33 & 22 & 13 \\
$41-50$ & 27 & 27 & 29 & 12 \\
$51-60$ & 16 & 15 & 18 & 7 \\
More than 60 & 30 & 14 & 22 & 19 \\
Total* & 100 & 100 & 100 & 100 \\
Number & 287 & 988 & 45 & 93 \\
\hline
\end{tabular}

*No data pertinent to this table were recorded for 32 of the 1,445 respondents.

\section{DESIRE FOR INFORMATION}

About half of the respondents, 755, expressed a need for at least one kind of landscaping information, and many wanted several kinds (Table 49). General Information was listed most, about twice as often as Disease and Pest Control, the next most frequent choice.*

Table 49. Information Desired About the Care of Trees and Shrubs (Respondents in the Northeast Region. 1959)

\begin{tabular}{l|c}
\hline \multicolumn{1}{c|}{ Kind of Information } & Frequency of Choice \\
\hline & Percent \\
\cline { 2 - 2 } General & 35 \\
Disease and Pest Control & 19 \\
Pruning & 15 \\
Use of Fertilizer & 10 \\
How to Plant & 6 \\
Where to Plant & 5 \\
What to Plant & 4 \\
How to Prepare Plants for Winter & 3 \\
Other & 3 \\
Total & 100 \\
Number & $1,357^{*}$ \\
\hline
\end{tabular}

*There were 755 respondents who expressed a need for information, but many wished several kinds of information.

*Significant. 
Data untabulated in this report show that husbands and wives differed only slightly in the frequency with which they expressed a need for information, but both education and age apparently influenced the desire for more information. The numbers of respondents wanting information increased as the level of education increased from elementary to high school and from high school to college.* As respondents' ages increased from less than 50 years to between 50 and 60 , and thence to more than 60 years, the desire for information decreased.*

When respondents were asked to suggest how nurserymen could improve their services to the public, about two-fifths said more information (Table 50). Suggestions for information services were about four times as numerous as any other.*

Table 50. Suggestions to Nurseries

(Respondents in the Northeast Region. 1959)

\begin{tabular}{l|r}
\hline \multicolumn{1}{c|}{ Suggestions } & Frequency of Suggestion \\
\hline & Percent \\
More Information & 43 \\
Lower Price & 11 \\
Better Stock & 8 \\
Guarantee & 7 \\
Less Sales Pressure & 6 \\
Better Informed Help & 6 \\
Follow-up to See How Plants Perform & 3 \\
Don't Misrepresent - & 2 \\
Other - & 14 \\
Total & 100 \\
Number & $521^{*}$ \\
\hline
\end{tabular}

* Only one suggestion per respondent was recorded.

Evidently there is a widespread desire among homeowners to know more about ornamental trees and shrubs, and accompanying this desire is a belief that nurserymen are not supplying adequate information services. Because this desire for information services increases as education increases, it also may increase as homeowners' income and buying power increase. Nurserymen apparently are failing to supply adequate information to the group of homeowners which might be expected to make the largest landscape expenditures. By dispensing informative literature, by consulting services, by informative talks and speeches, nurserymen might influence homeowners to replace undesirable species, to remove misplaced ornamentals, and to relandscape more effectively.

\section{ATTITUDE TOWARD NURSERY AND CHAIN STORE PURCHASING}

To obtain data about homeowners' attitudes toward purchasing ornamentals from nurseries and from chain stores, statements about such

*Significant. 
purchasing were read to each respondent. After each statement had been read, the respondent was asked to indicate; strongly agree, agree, undecided, disagree, or strongly disagree. Each respondent's reactions were tabulated and scaled into five gradations of attitude. ${ }^{6}$ For purposes of this report, respondents were classified as favorable, strongly favorable, undecided, unfavorable, or strongly unfavorable. Table 51 shows the resultant compilation.

\section{Table 51. Attitudes Toward Nurseries and Chain Stores (Respondents in the Northeast Region. 1959)}

\begin{tabular}{l|c|c}
\hline \multirow{2}{*}{\begin{tabular}{c|c} 
Ratings \\
\end{tabular}} & $\begin{array}{c}\text { Respondents } \text { Rated by } \text { Attitudes } \\
\text { Nurseries }\end{array}$ & $\begin{array}{c}\text { Toward } \\
\text { Chain Stores }\end{array}$ \\
\hline & Percent & Percent \\
\hline Strongly Favorable & 35 & 23 \\
Favorable & 14 & 15 \\
Undecided & 21 & 32 \\
Unfavorable & 19 & 17 \\
Strongly Unfavorable & 11 & 13 \\
Total Number & 100 & 100 \\
$\quad$ & $1,419^{*}$ & $1,419^{*}$ \\
\hline
\end{tabular}

*There were 26 respondents whose responses were irrelevant to the preparation of this table.

Strongly favorable attitudes were much more frequent toward purchasing at nurseries than at chain stores; ${ }^{*}$ and relatively more respondents were undecided about chain store purchasing than about purchasing at nurseries.* Apparently homeowners tend to have positive attitudes about purchasing at nurseries-usually favorable. However, their attitudes toward purchasing ornamentals at chain stores tend to be moderate.

Data not listed in table form indicate that education, age of respondent, and family income do not exert significant patterns of influence upon attitudes toward nurseries and chain stores. There were occasional relationships which seemed to be irrelevant. For instance, the proportions strongly in favor of purchasing from nurseries and strongly opposed to such purchases were greatest among respondents whose formal education had ceased after elementary school. The proportions of respondents mildly favorable and mildly unfavorable within the same educational bracket were correspondingly low. Possibly this group of homeowners either speaks in superlatives or expresses no opinions.

Relatively more respondents were strongly unfavorable to nursery purchases if they had not made such purchases than if they had.* Con-

6 An explanation of the technique used may be found in "Measurement and Prediction," Studies in Social Psychology in World War II, Vol. 4, Princeton. 1950. Samuel A. Stauffer, Louis Guttman, et al.

* Significant. 
versely, the proportion strongly favorable to nursery purchases was greater among those who had made such purchases than among those who had not.* Possibly homeowners speaking from experience tend to favor nursery purchases, or owners who already favor such purchases tend to make them.

The analysis indicates that homeowners usually prefer to purchase ornamentals at nurseries than at chain stores. However, the difference is rather pronounced between stated preferences and actual practices in purchasing ornamentals. Only about half of the respondents reacted favorably to nurseries on the basis of stated preferences, but in 1958 they actually purchased about seven times as many ornamentals from nurseries as from chain stores (Table 3). Present attitudes may indicate future trends in purchasing, and retail nurserymen may lose an increasing amount of trade to chain stores. However, by increasing favorable attitudes among homeowners, nurserymen might minimize a consumer shift to purchasing more trees and shrubs at chain stores.

\section{ATTITUDES TOWARD LANDSCAPING}

To measure attitudes toward landscaping, respondents were requested to register agreement or disagreement to 19 statements. Each respondent's answers were scored 0 through $9,{ }^{7}$ the latter score indicating the most favorable category. Table 52 shows attitude groupings based upon respondents' scores.

Table 52. Attitudes Toward Landscaping

(Respondents in the Northeast Region. 1959)

\begin{tabular}{|c|c|c|c|}
\hline & Attitude Rating & Score & Respondents \\
\hline & & \multirow{10}{*}{$\begin{array}{r}0 \\
1 \\
2-3 \\
4-5 \\
6-7 \\
8 \\
9\end{array}$} & Percent \\
\hline & Least Favorable & & 1 \\
\hline & & & $0^{*}$ \\
\hline 3. & .................. & & $0^{*}$ \\
\hline 4. & 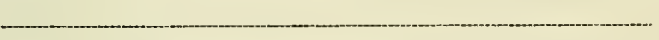 & & 10 \\
\hline 5. & 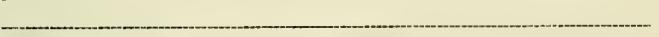 & & 66 \\
\hline 6. & 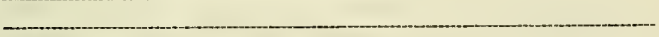 & & 23 \\
\hline & Most Favorable & & 0* \\
\hline & tal & & 100 \\
\hline & Number & & 1,445 \\
\hline
\end{tabular}

*Less than $1 / 2$ of 1 percent.

About nine-tenths of the respondents scored 6 or better, and only one one-hundredth scored 1 or less. However, the least favorable respondents were more numerous than the two next lowest categories.*

7 An explanation of the technique used may be found in "Theory of Measurements," Psychological Bulletin 36, pp. 249-269. 1929. L. L. Thurstone.

*Significant. 
In Table 53 respondents who rated the least favorable to landscaping are classified by several categories. Those who were unwilling to report their incomes, who were more than 60 years old, and who lived in comparatively old houses were least favorable relatively more often than other respondents.* Possibly the attitude suggested by these data was more a reflection of reactions toward interviews and interviewers than toward landscaping.

Table 53. Least Favorable Attitudes Toward Landscaping (Distribution of respondents among three categories where the rate of recurrence was highest. Northeast Region. 1959)

\begin{tabular}{|c|c|c|c|c|}
\hline \multirow[b]{2}{*}{ Categories* } & \multicolumn{2}{|c|}{ Attitudes } & \multirow{2}{*}{\multicolumn{2}{|c|}{ Total }} \\
\hline & $\begin{array}{c}\text { Least } \\
\text { Favorable }\end{array}$ & Others & & \\
\hline & Percent & Percent & Percent & Number \\
\hline Family Income Not Reported & 11 & 89 & 100 & 112 \\
\hline Respondents More Than 60 Years Old & 4 & 96 & 100 & 260 \\
\hline Homes More Than 20 Years Old & 2 & 98 & 100 & 725 \\
\hline All Respondents & 1 & 99 & 100 & 1,445 \\
\hline
\end{tabular}

*These three categories do not include all respondents, and one respondent might occur in all three categories.

*Significant. 


\section{(QUESTIONS ASKED TO DETERMINE ATTITUDES)}

\section{Attifudes Toward Nurseries and Chain Słores}

A. Purchases at nurseries are worthwhile but one must buy with care.

SA

A U D

SD

Information given by nurseries is often useful.

I do not trust product guarantees given by nurseries.

Products sold in nurseries are generally healthy.

I think the price of plants sold in nurseries is often too high.

\begin{tabular}{|c|c|c|c|c|}
\hline 5 & 4 & 3 & 2 & 1 \\
\hline 5 & 4 & 3 & 2 & 1 \\
\hline 1 & 2 & 3 & 4 & 5 \\
\hline 5 & 4 & 3 & 2 & 1 \\
\hline 1 & 2 & 3 & 4 & 5 \\
\hline 1 & 2 & 3 & 4 & 5 \\
\hline 5 & 4 & 3 & 2 & 1 \\
\hline 1 & 2 & 3 & 4 & 5 \\
\hline 5 & 4 & 3 & 2 & 1 \\
\hline 5 & 4 & 3 & 2 & 1 \\
\hline 1 & 2 & 3 & 4 & 5 \\
\hline 1 & 2 & 3 & 4 & 5 \\
\hline 5 & 4 & 3 & 2 & 1 \\
\hline 1 & 2 & 3 & 4 & 5 \\
\hline
\end{tabular}

I have little confidence in the quality of products sold in nurseries.

I think that nurseries offer a wide enough choice of products.

It is rare that one obtains full satisfaction from plants bought in nurseries.

B. Purchases of plants in chain stores are worthwhile but one must buy with care.

Plants sold in chain stores are generally healthy.

I think the price of plants sold in chain stores is often too high.

I have little confidence in the quality of plants sold in chain stores.

I think that chain stores offer a wide enough choice of plants.

It is rare that one obtains full satisfaction from plants bought in chain stores.

C. With retail prices the same, it is easier to obtain full satisfaction from plants bought in nurseries than from plants bought in chain stores.

It is easier to get a bargain in a chain store than in a nursery.

Is is very often more worthwhile to buy in a chain store than in a nursery.

With retail prices the same, one can get better plants in a nursery than in a chain store.

\begin{tabular}{ccccc}
\hline 5 & -4 & 3 & 2 & 1 \\
-1 & -2 & -3 & -4 & $\frac{5}{4}$ \\
\hline 1 & -2 & -3 & -4 & $\frac{5}{4}$ \\
\hline 5 & 4 & 3 & 2 & 1 \\
-5 & $-\frac{1}{4}$ & -3 & $-\frac{2}{2}$ & $\frac{1}{1}$
\end{tabular}

One is always better off to buy plants in a nursery than in a chain store. 
I like the end results of landscaping but it involves too much work.

The more I know about landscaping, the more I would like my property landscaped.

Without good landscaping even the best designed house fails to be fully appreciated.

The budget-minded home owner will always invest in landscaping.

The prospective home owner is always very interested in good landscaping.

Landscaping is an effort to "keep up with the Joneses".

I think that trees and shrubs are impractical for a family with several children.

Landscaping would be fine if I had more time.

I think that landscaping is the best home improvement that one can attempt.

For a home, nothing is more important that good landscaping.

Landscaping a house costs too much money for the end results.

Nothing gives as much satisfaction to a homeowner as a well landscaped lawn.

The prospective buyer of a home looks at the landscaping of the property before looking at the house.

I consider landscaping as one way of wasting money

Everyone should landscape his property to make towns more beautiful.

I do not pay too much attention to landscaping but I would not like to see my attitude become general.

Landscaping beautifies a house more than anything else.

I consider landscaping the most essential part of a property.

Landscaping a property increases its market value several times as much as the cost for trees and shrubs. 



